\title{
An Open Access Distribution Tariff: Removing Barriers to Innovation on the Smart Grid
}

\author{
Joel B. Eisen
}

\begin{abstract}
This Article proposes that the Federal Energy Regulatory Commission (FERC) consider promulgating an Open Access Distribution Tariff (OADT) to open the nation's electric grid to new products and services at the consumer (distribution) level. Design of the OADT would be comparable to the Open Access Transmission Tariff that the FERC has used previously to open the nation's transmission wires. This Article argues that an OADT is necessary to create a smart electricity network that would be national, multimodal, and interactive. There is no smart electricity network at present, and there are numerous barriers to the development of open networking, such as obstacles to open access, lack of consumer demand for such a network and its products, resistance of incumbent utilities, and a variety of other factors. An open access principle will likely be necessary, but the timing of such regulation is of critical importance. This Article argues that regulatory establishment of an open access principle will eventually be necessary — and to assess when open access might be desirable, this Article examines the revolutionary transformations that took place in three regulated industries: telecommunications, electricity restructuring, and finance.
\end{abstract}

This Article examines key near-term and long-term questions involving an OADT's timing and development by analyzing these regulated industries using three criteria: (1) signifiers of when a transition would be necessary and conditions that might make open access more desirable to industry actors, (2) regulatory prerequisites necessary in the near term, and (3) risks involved in drawing lessons from the specific regulatory transformation (including federalism concerns). This Article concludes that rather than waiting for an organic transformation of the electric grid and evolution of open networking, a deliberate path of preparatory work will best set the foundation for open access.

\section{AUTHOR}

Joel B. Eisen is a Professor of Law and Austin Owen Research Fellow at the University of Richmond School of Law. The author thanks the participants in the UCLA Law Review Symposium, Towvard a Clean Energy Future: Powering Innovation with Law (with special thanks for comments from Ann Carlson and William Boyd), and the participants in the Northwestern Law Searle Center Conference on Federalism and Energy in the United States for their feedback and comments. The author also thanks Emily Hammond, Alexandra Klass, Amy Stein and Joseph Tomain for their invaluable comments on earlier 
drafts, and thanks Allison Rienecker and Daniel Savage for their research assistance, and Joel Bernstein of Temple Strategies for assistance on telecommunications law and policy issues. Fellow participants in the First Aspen Institute Initiative on Smart Energy and Network Technologies Roundtable, in Queenstown, Maryland in May 2013, were especially helpful in discussing issues associated with smart electricity networks.

\section{TABLE OF CONTENTS}

INTRODUCTION.

I. The Smart Electricity Network and Open Access ...............................1718

A. Where We Are Today: No Network, but Lots of Promise ....................1718

B. The Challenge of Consumer Demand ...............................................1721

II. Open Access Through an OADT: What Is It, and Under What

Circumstances Is It Necessary? .........................................................1723

A. The Open Access Distribution Tariff .............................................. 1724

B. Is an OADT Necessary?................................................................1726

III. Models for Open Access: Lessons for Policy Evolution ......................1730

A. The Telecommunications Model ......................................................1730

1. Appeal of the Telecommunications Model .................................1731

2. Regulatory Evolution and Effects of the 1996 Act.......................1733

3. Lessons for a Smart Electricity Network ...................................1738

a. Signifiers That a Transition to Open Access Is Possible .......1738

b. Necessary Regulatory Prerequisites....................................1740

c. Risks in Relying on the Model..........................................1746

d. Final Thoughts About the Telephone Model........................1748

B. The Electricity Model......................................................................1749

1. Regulatory Evolution and Appeal of the Electricity Model ..........1749

2. Lessons for a Smart Electricity Network ....................................1750

a. Signifiers That a Transition to Open Access Is Possible .......1750

b. Necessary Regulatory Prerequisites...................................1752

c. Risks in Relying on the Model..........................................1754

C. The Finance System Model (Dodd-Frank)........................................1758

1. The Appeal of the Financial System Model................................1759

2. Regulatory Evolution Leading to the Creation of the CFPB .......1761

3. Lessons for a Smart Electricity Network....................................1766

a. Regulatory Lessons ........................................................1766

b. Risks in Relying on the Model..........................................1768

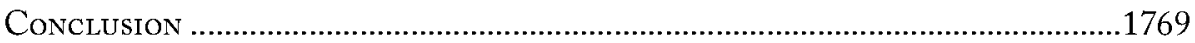




\section{INTRODUCTION}

Hardly a day goes by without some call for transformative regulatory change to the U.S. electric grid to promote the development and deployment of revolutionary technologies. ${ }^{1}$ This Article introduces and discusses a means of accelerating that transformation, an open access distribution tariff (OADT). As the name suggests, the OADT would be implemented by a Federal Energy Regulatory Commission (FERC) rule, ${ }^{2}$ modeled upon FERC's Order 888, which provided the foundation for opening the nation's transmission grid and spurring electric industry restructuring. ${ }^{3}$ The purpose of the OADT would be to create a smart electricity network ${ }^{4}$ that would replace the current linear model of delivering electricity. This smart electricity network would feature a multimodal grid with supply, demand, and network management all taking place at multiple nodes on the network ${ }^{5}$ and transactive energy (multi-directional transactions taking place in the system). ${ }^{6}$ In today's electric grid, this would involve access to existing distribution wires, unless

1. See, e.g., Davide Savenije, Ron Binz Predicts 3 Changes Coming to Utility Regulation, UTILITY DIVE (Oct. 18, 2013), http://www.utilitydive.com/news/ron-binz-predicts-3-changes-coming-to-utilityregulation/183326. Ron Binz, former Chairman of the Colorado Public Utilities Commission and unsuccessful choice for Federal Energy Regulatory Commission (FERC) Chairman, states that "[i]t's very clear that U.S. regulation needs an overhaul in a very fundamental way." Id.

2. A FERC Order requiring utilities to adopt open access distribution tariffs (OADTs) would raise obvious jurisdictional issues. See discussion infra Part III.

3. See Promoting Wholesale Competition Through Open Access Non-Discriminatory Transmission Services by Public Utilities; Recovery of Stranded Costs by Public Utilities and Transmitting Utilities, 61 Fed. Reg. 21,540 (Apr. 24, 1996) [hereinafter FERC Order 888], available at http://www. ferc.gov/legal/maj-ord-reg/land-docs/rm95-8-00w.txt (to be codified at 18 C.F.R. pts. 35, 385).

4. While the term "Smart Grid" has arisen to describe the concepts, technologies, and operating practices that may revolutionize the staid electric grid and redefine electricity generation, distribution, and use, this Article prefers the term "smart electricity network" to highlight a central attribute of this transformation and aim of the OADT: multidirectional networking. See, e.g., Joel B. Eisen, Smart Regulation and Federalism for the Smart Grid, 37 HARV. ENVTL. L. REV. 1, 2-3 (2013).

5. DAVE GROSSMAN, ASPEN INST., ADVANCING SMART ELECTRICITY NETWORKS 1-2 (2013) [hereinafter ASPEN INST.], available at http:/www.aspeninstitute.org/sites/default/files/content/ images/INSENT\%202013\%20Report\%20FINAL.pdf("[A] smart electricity network, in contrast, has supply, demand and network management happening everywhere. End use, for example, can be not only a source of demand but also a source of supply (e.g., rooftop solar).").

6. See Transactive Energy, GRIDWISEAC, http://www.gridwiseac.org/about/transactive energy.aspx (last updated Feb. 2014). For a perspective critical of the term "transactive energy," see Michael T. Burr, Who's Afraid of the Transactive Grid?, PUB. UTIL. FORT., Aug. 2013, at 4 (calling the term a "buzzword" and an unnecessary shorthand for describing ongoing developments on the grid). 
storage or some other nonwire solution displaces them. ${ }^{7}$ A smart electricity network would most likely be layered on top of the existing one without physically displacing it.

The central aim of the OADT would be to make this network open and freely accessible for purchases and sales of electricity. Under the FERC Order, public utilities that FERC regulates would be required to file tariffs to open their electric distribution lines to all purchasers and sellers of electricity, and all providers of energy services. Utilities would be required to offer the same terms, rates, and conditions to all users, effectively imposing a common carrier obligation on distribution line owners. The Order would create a system providing transparent and readily accessible information and would preempt state laws hindering network transactions. The implications are staggering. Under an OADT, for example, an individual homeowner with solar panels could sell excess electricity freely to a resident of another state, or sell it into the regional wholesale electricity markets now existing in roughly half the nation.

As this brief introduction suggests, the idea of an OADT is radically new and complex, with many variables that would need further definition. For example, "open access" is not self-defining, ${ }^{8}$ and FERC would need to make a number of difficult decisions about the terms and conditions of access. Currently, there is no consensus about the network architecture or objectives that a smart electricity network would promote. The possibility even exists that today's Smart Grid ${ }^{9}$ may become part of a broader Internet of Things. ${ }^{10}$ For purposes of discussion, this Article assumes this is a realistic possibility, but it also recognizes that ongoing initiatives to build toward a Smart Grid will continue and discussing an open access principle for the Smart Grid is important.

7. See Cal. Pub. Util. Comm'n, Decision Adopting Energy Storage Procurement Framework and Design Program, R.10-12-007 (proposed Oct. 17, 2013) (adopting a framework for energy storage procurement in California and calling for 1,325 MW of storage capacity for the three major investor-owned utilities in California by 2020 pursuant to CAL. PUB. UTIL. CODE $§ 2836$ (West 2013)). For a discussion of federal regulation of energy storage and prospects for further expansion, see Amy L. Stein, Reconsidering Regulatory Uncertainty: $A$ Path Forward for Energy Storage, 41 FLA. ST. U. L. REV. (forthcoming 2014) (manuscript on file with author).

8. See, e.g., Agustin Diaz-Pines, Stimulating Competition Through Open Access Networks, OECD INSIGHTS (Mar. 5, 2013), http://oecdinsights.org/2013/03/05/stimulating-competition-throughopen-access-networks.

9. See, e.g., Eisen, supra note 4, at 1-2.

10. See Emily Adler, Here's Why The Internet of Things' Will Be Huge, and Drive Tremendous Value for People and Businesses, BUS. INSIDER (Dec. 7, 2013, 9:38 PM), http://www.businessinsider.com/growth-inthe-internet-of-things-2013-10 (including "Smart electricity grids" as one part of the evolving network). 
According to one recent definition, a smart electricity network is "an open-access, multi-directional transactional platform that enables optimization of a range of objectives ... . includ[ing] not only those objectives that are the foundation of the current electricity system (providing universal, affordable, reliable, and safe power), but also new objectives such as enabling clean power, distributed generation, consumer choice, and innovation." 11 That long-and at times inherently contradictory-list illustrates that the network's eventual character is yet to be defined in any meaningful way.

While the promise of a smart electricity network is great, there are numerous obstacles to its innovation. One formidable barrier is the ongoing federal-state tension in electricity regulation. For many issues relating to the smart electricity network, "decisions have to be made about the level of government at which regulation should occur and the model for cooperation (or lack thereof) between the different levels of government." ${ }^{12}$ In one early court battle over the distribution of regulatory jurisdiction, a D.C. Circuit panel held that FERC could not use its authority over wholesale electricity markets to require market pricing of a resource offered into those markets (blocks of demand response, involving aggregated reductions of electricity consumption in response to incentives), although there may be a different outcome on rehearing. Other challenges to new FERC rules are pending.

Another challenging barrier to open access is the control of distribution wires by incumbent utilities. In some states, utilities have fought programs that might lead to smart electricity networking, such as expanded net metering that allows consumers to sell excess power to the electric grid. Still another obstacle is the lack of consumer demand for a smart electricity network and its products and services. Given the dearth of plug-and-play products, services, and business models, development of a smart electricity network is unlikely to be consumer-driven. This means that unless some entity or entities builds network infrastructure to prompt consumer demand (and therefore, at least at the start, with some speculation as to what might do this), the potential benefits such as consumer choice and cleaner generation are unlikely to materialize.

Overcoming these barriers requires both new technologies and transformative regulatory change. Development of a smart electricity network will occur in part through natural evolutionary change. Federal and state governments already encourage the development and deployment of new potentially disruptive technologies in the electricity sector. Moreover, some commenta-

11. ASPEN INST., supra note 5, at v.

12. Id. at 13 . 
tors have noted that establishing key high-level standards, frameworks, and related principles can help direct network development. ${ }^{13}$ The central question for the smart electricity network is whether we will still need more regulatory intervention.

This Article argues that a regulatory open access principle will eventually be necessary. Part I concludes that the current grid, even with the changes currently envisioned, is far from a national, multimodal network and does not yet incorporate interactive strategies, opportunities, and business models for electricity generation, use, and management. Part I also examines the problem of the current low consumer demand for interactive applications and concludes that a network must evolve in the absence of strong demand.

Such a claim invites a central question: Under what conditions, and when should we establish a principle of openness? If the network would happen without further intervention by the accretion of laws and policies favoring technologies at the edge of the grid over the coming years, an OADT would not be needed. Part II challenges that assumption, and argues that an OADT would facilitate a transition to networking by overcoming resistance on the part of incumbent utilities.

To focus more closely on the timing and conditions of the transformation to openness, Part III examines three examples of dramatic change and regulatory transformation in different industries: telecommunications, electricity restructuring, and finance following the financial meltdown of the Great Recession. No one example will yield a precise prediction of exactly how we'll evolve toward a smart electricity network. But these dramatic transformations taken together have much predictive guidance to offer.

The Article argues that proponents of a smart electricity network can learn many useful lessons from these examples about two specific parameters: (1) signifiers that would help policymakers determine when the transformation to open access is appropriate (and conditions that might make open access more desirable to industry actors), and (2) regulatory prerequisites necessary in the near term (given that open access is proposed for some future date). In addition, the discussion of each example analyzes risks involved in relying on any one particular combination of timing and regulatory transformation, including federalism concerns.

Part III illustrates how each of these parameters and risks operated in the three examples and suggests key near-term and long-term questions surrounding an OADT's timing and development. For the financial systems

13. See, e.g., Eisen, supra note 4, at 3-4. 
model, Part III discusses important lessons we can learn from financial reform, which did not result in open access on a network, in place of the two parameters. The analysis in Part III suggests key near- and long-term questions for an OADT's timing and development. The Article concludes by outlining the necessary prerequisites for, and barriers to, fundamental transformation of the electric utility industry.

\section{THE SMART ELECTRICITY NETWORK AND OPENACCESS}

\section{A. Where We Are Today: No Network, but Lots of Promise}

At present, we have no smart electricity network. Network designers often make a distinction between network infrastructure and applications that take advantage of that infrastructure. ${ }^{14}$ We currently have neither. Instead, we have an existing infrastructure without network capabilities and with substantial barriers to open networking, including the presence of monopoly owners at a critical bottleneck (the distribution lines). This is the opposite of a network. Call it a non-network.

As multiple observers have noted, the electric grid is not smart. ${ }^{15}$ The U.S. electric grid is an engineering marvel that reliably provides universal, affordable, reliable, and safe electricity. No one would seriously contend that it is technically flawed, notwithstanding its occasional large-scale brownouts and other failures. ${ }^{16}$ Yet the grid is largely stuck in the twentieth century. Today's infrastructure is predominantly "linear, with one-directional flow from generation (supply) to transmission and distribution (network management) to end use (demand)." 17

For the moment, there is no network, but seeds of revolutionary technologies are everywhere. Many of these, including distributed generation, plug-in electric vehicles, demand response, energy efficiency, and microgrids, could take advantage of a network if one were available, especially if supported by aggressive governmental policies such as renewable portfolio stand-

14. See Cisco Sys., NeTwork AND APpliCation Management MAde Simpler 1 (2012), www.cisco.com/web/solutions/medianet/docs/whitepaper_c11-698465_v2.pdf.

15. Cf. Mass. Inst. of Tech. EnERgy Initiative, THE Future of THE Etectric Grid 1-3 (2011), available at http://mitei.mit.edu/system/files/Electric_Grid_Full_Report.pdf (discussing the limitations of today's electric grid).

16. See generally id:;. MICHAEL BARRETTET AL., LEXINGTON INST., ENSURING THE RESILIENCE OF THE U.S. ELECTRICAL GRID 5-6 (2013), http://www.lexingtoninstitute.org/library/resources/ documents/Energy/EnsuringResilienceofUSElectricalGrid.pdf (discussing the electric grid's resilience and the risk of systemwide failures).

17. ASPEN INST., supra note 5, at 3. 
ards. ${ }^{18}$ Which technologies on the "edge" of the grid will emerge as potential large-scale competition to incumbent utilities? That is not clear.

Nor, for that matter, is another critical aspect of the network clear: whether developers of new energy resources would even seek to use it. The disruptive character of many energy applications on the grid's edge is their ability to replace electricity provided by utilities. Producers could add generation capacity or demand response to the grid, but they might also detach themselves from the grid altogether and create independence from utilities by self-generating or pursuing strategies to curb demand. ${ }^{19}$

Discussions of developing electricity resources at the edge of the grid often conflate these two possibilities, as in the case of microgrids, which could be independent islands or connected to the grid. ${ }^{20}$ Much of the contemporary discussion about developing alternatives to traditional utilities does not presuppose a specific form for the network to which these new resources might connect. Yet that is obviously important to know. If producers intend to provide electricity to others across the network, they would encounter problems with the distribution system. To use an interstate highway analogy, it is impossible to decide whether all are entitled to use the highway if private companies control the entrance ramps.

The potential connections on the network could take a variety of forms, including nonlinear ones. What seems settled is that the network is not likely to be a full-blown new infrastructure, but rather will consist of improvements to the old infrastructure, such as deployment of smart meters and digital technology across the existing network. We must acknowledge, however, that at some point it might be technically possible to develop a completely new network, such as wireless transmission, if the technology advances enough. ${ }^{21}$

18. See, e.g., Most States Have Renewable Portfolio Standards, U.S. ENERGY INFO. ADMIN. (Feb. 3, 2012), http://www.eia.gov/todayinenergy/detail.cfm?id=4850; DATABASE OF STATE INCENTIVES FOR RENEWABLES AND EFFICIENCY, RENEWABLE PORTFOLIO STANDARD POLICIES, http://www.dsireusa.org/documents/summarymaps/RPS_map.pdf (last visited Sept. 13, 2013) (discussing and mapping state RPSs).

19. See, e.g., Rebecca Smith \& Cassandra Sweet, Companies Unplug From the Electric Grid, Delivering a Jolt to Utilities, WALL ST. J. (Sept. 17, 2013), http://online.wsj.com/news/articles/SB10001 424127887324906304579036721930972500 .

20. See Justin Gerdes, How Microgrids are Bolstering the Nation's Power Infrastructure, SMITHSONIAN (Nov. 15, 2013), http:/www.smithsonianmag.com/science-nature/how-microgrids-are-bolsteringthe-nations-power-infrastructure-180947705. See generally Sara C. Bronin, Curbing Energy Sprawl With Microgrids, 43 CONN. L. REV. 547 (2010).

21. See Brian Dumaine, Electric Power Without Lines, CNN MONEY (Nov. 1, 2013, 9:21 AM), http://tech.fortune.cnn.com/2013/11/01/wireless-electricity (describing companies that are investing in development of the technology). 
Defining a smart electricity network introduces circularity into the discussion. What is smart can mean many things to many people, encompassing a wide range of functions, goals, and attributes. Does a smart electricity network operate like the Internet, with fast, digital connections everywhere? Does it have improved operational efficiencies, such as faster outage and restoration capabilities, and better ability to manage volatile supply and demand conditions? Is it secure? Reliable? Private? Is it cleaner than today's grid, with more renewable energy, demand response, and energy efficiency? That last objective might be a paramount goal for some, particularly those concerned about the climate change impacts of electricity generation. For those actors, we should design the network explicitly with that goal front and center. ${ }^{22}$

To enumerate this list of objectives is to observe that many of them are contradictory. It is not self-evident, for example, that a more rapid and reliable network would necessarily be cleaner. A more efficient network could predominantly rely on fossil fuels, especially natural gas, given the rapid increase in its availability at low prices, its displacement of coal in the generation mix, and the ease with which newer plants can ramp up to meet surges in demand. ${ }^{23}$

To sum up, there is little to no common understanding about three distinct questions: what form the network infrastructure will take ${ }^{24}$; what multidirectional connections the network makes possible; and what goals are being pursued (such as more clean energy, more support for disruptive innovations, and so forth). The multiplicity of decision makers, including federal regulatory agencies, state public utility commissions (PUCs), utilities, regional transmission grid operators, and others, virtually guarantees that this conversation will be years in the making. Furthermore, as the dialogue is proceeding, there is tremendous dissonance. It is extraordinarily difficult to separate out "what the network is from how we would like it to operate and why we are pursuing it ...."25

22. See, e.g., Elias L. Quinn \& Adam L. Reed, Envisioning the Smart Grid: Network Architecture, Information Control, and the Public Policy Balancing Act, 81 U. COLO. L. REV. 833, 834-39 (2010); Steven Ferrey, Restructuring a Green Grid: Legal Challenges to Accommodate New Renervable Energy Infrastructure, 39 ENVTL. L. 977 (2009).

23. See Wendy Koch, U.S. Forecasts Natural Gas Boom Through 2040, USA TODAY (Dec. 16, 2013, 10:56 AM), http://www.usatoday.com/story/news/nation/2013/12/16/doe-forecastnatural-gas-boom/4034723.

24. The development of interoperability standards is beginning to provide a technical foundation. See Eisen, supra note 4, at 23-26.

25. ASPEN INST., supra note 5, at 2; see also Quinn \& Reed, supra note 22, at 839 ("Many decisions regarding [smart grid's] network architecture-the actors, physical means, and legal entitlements by which data is collected, aggregated, analyzed, utilized, provided, or sold to 
Yet even amidst this near-term uncertainty, a gradual consensus of sorts is developing. First, technologies either being deployed today or envisioned for the near future are shifting the locus of electricity production toward the edge of the grid. ${ }^{26}$ Second, these technologies are potentially disruptive to the existing utility business model..$^{27}$ Third, while resources are not yet coordinated on a network, they hold the promise of change to the one-way system, possibly leading to a fully multidirectional network. ${ }^{28}$ Finally, our notion of "the way energy is sold, purchased, and used [may] fundamentally change" with a "dematerialization" similar to that taking place in the music industry, marked by "a shift from providing a commodity to providing a service." ${ }^{29}$

\section{B. The Challenge of Consumer Demand}

How could a smart electricity network benefit consumers? Many observers believe that consumers would have numerous new choices in terms of service, responsiveness, and applications that would yield environmental and economic benefits. ${ }^{30}$ To name just a few potential applications, providing consumers with fine-grained data on electricity usage could help them understand how much electricity they use, which in turn could prompt reduced consumption and environmental benefits. ${ }^{31}$ The data gathered by smart meters may well "create a 'big data' ecosystem in which analytics will be essential for devising products and services for which consumers might be willing to pay." 32 Specific services and programs, such as sophisticated energy management sys-

interested parties (be they consumers, utilities, data brokers, or others)—are not yet standardized, and in many cases these decisions are almost entirely unformed.").

26. See BRACKEN HENDRICKS \& ADAM SHEPARD JAMES, CTR. FOR AM. PROGRESS, THE NETWORKED ENERGY WEB: THE CONVERGENCE OF ENERGY EFFICIENCY, SMART GrID, AND Distributed POWER Generation as THE NEXT FrontIER OF THE ICT REVOLUTION 5-6 (2012), available at http://www.americanprogress.org/wp-content/uploads/ 2012/08/0709_CleanEnergyWeb1.pdf.

27. PETER KIND, DisRUPTIVE CHALLENGES: FINANCIAL IMPLICATIONS AND STRATEGIC RESPONSES TO A CHANGING RETAIL ELECTRIC BUSINESS 19 (2013), http://www.eei.org/ ourissues/finance/Documents/disruptivechallenges.pdf.

28. HENDRICKS \& JAMES, supra note 26, at 6 ("[W] here electricity generation, transmission, and distribution, and consumer end use were once entirely distinct segments of the electricity grid, all nodes of the emerging networked energy web are increasingly more tightly interconnected, with producers, consumers, and grid operators all playing greater roles in optimizing supply, demand, and grid operations.").

29. ASPEN INST., supra note 5, at 3.

30. Inst. of Elec. and Electronics Eng'rs, Smart Grid Consumer Benefits, IEEE SMART GRID (Sept. 4, 2013), http://smartgrid.ieee.org/questions-and-answers/964-smart-grid-consumer-benefits.

31. Id.

32. ASPEN INST., supra note 5, at 4-5. 
tems, could be developed for targeted customer groups or even for individual consumers. ${ }^{33}$

But this presents a classic chicken and egg situation. Consumer demand for the network is likely to be weak until the network infrastructure exists. ${ }^{34}$ Those who might benefit from a smart electricity network-consumershave little to no knowledge about the concept ${ }^{35}$ and have demanded neither the network nor the products and services it would feature. Smart meters are just now being deployed widely and the components of the network are just emerging. ${ }^{36}$ Many observers have noted that even with increasing penetration of edge technologies such as distributed solar photovoltaic systems, there is still relatively low consumer demand for these products and services. As Reed Hundt, former chairman of the Federal Communications Commission (FCC), noted, "[A]lmost no one wants to buy any of the outcomes of any [green] business models." ${ }^{37}$ But a recent report on state banks providing incentives for the financing of energy projects gives some cause for optimism. ${ }^{38}$ In general, widespread availability of power purchase agreements, leases, feed-in tariffs, ${ }^{39}$ and other creative means of financing ${ }^{40}$ may prompt a dramatic increase in residential solar uptake. For now, however, solar still provides a small fraction of total generating capacity. ${ }^{41}$

33. IEEE, supra note 30.

34. ASPEN INST., supra note 5, at ix-x.

35. Cf. Most Consumers Feel They Only Moderately Understand How Smart Grid Technology Works, PR NEWSWIRE (Mar. 29, 2011), http://www.prnewswire.com/news-releases/most-consumersfeel-they-only-moderately-understand-how-smart-grid-technology-works-118834499.html.

36. ASPEN INST., supra note 5, at 6 ("Some isolated building blocks of the network infrastructure are already in place (e.g., neighborhood-scale solar, tri-gen plants), and there will be more incremental advancements that make the business case for a much bigger transformation.").

37. Id. at 5 .

38. See generally Bracken HeNdRICKS \& Ben Bovarnick, CTR. For AM. Progress, BANKInG

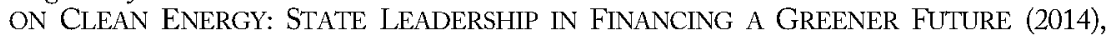
available at http://www.americanprogress.org/issues/green/news/2014/01/17/82355/banking-onclean-energy-state-leadership-in-financing-a-greener-future-2 (noting that state green banks are becoming increasingly more successful at steering capital to renewable energy projects).

39. See BOSSELMAN, EISEN, ET AL., Renewable Energy Sources, ENERGY, ECONOMICS AND THE ENVIRONMENT chs. 11-12 (4th ed., forthcoming 2014) for a comprehensive discussion of these incentives.

40. The start-up firm Solar Mosaic, for example, uses crowdsourcing-aggregating investments from numerous investors to fund projects. See Ucilia Wang, Mosaic Plans Overseas Expansion With Its Kickstarter-Style Solar Campaigns, FORBES (Jan. 8, 2014, 4:58 PM), http://www.forbes.com/ sites/uciliawang/2014/01/08/mosaic-plans-overseas-expansion-with-its-kickstarter-style-solarcampaigns; SOLARMOSAIC, https://joinmosaic.com.

41. See Annual Energy Outlook 2013: Market Trends-Electricity, U.S. ENERGY INFO. ADMIN., http://www.eia.gov/forecasts/aeo/MT_electric.cfm (last visited Feb. 1, 2014) (noting that solar technologies combined account for less than five gigawatts of capacity nationwide). 
There is also much that we do not know about consumer behavioral preferences with respect to electricity consumption. The literature on the subject is just now advancing to the point where researchers can monitor and understand the impact of changes in infrastructure, pricing, and applications on individual consumption. Until very recently, there has been little sophisticated data, as smart meters have only lately become widely available. So we cannot yet know whether more widespread networking will require easy-touse devices and applications that handle sophisticated decisions - the electricity equivalent of smart phones-without a lot of consumer input. ${ }^{42}$

Networking may also take new business models. ${ }^{43} \mathrm{We}$ may need creative bundling of services or pricing options (such as the cellphone system's use of fixed prices for specific services or levels of usage). The existing situation "is . . . very far from plug-and-play capability, where someone could go to the store, buy a little backyard vertical wind turbine, easily plug it into their electrical system, and have a panel in the home recognize and draw power from the new generation source." ${ }^{34}$ Without this simplicity of service and choice, we may not see widespread demand for a smart electricity network.

Currently, then, the private sector will not establish a smart electricity network on its own, as individual firms have not built out the network infrastructure. For that reason, the network is a public good that requires public investment before consumers want it and before open access principles are in place. The interoperability standards may well promote this goal. ${ }^{45}$

\section{OPENACCESS THROUGH AN OADT: WHAT IS IT, AND UNDER WHAT CIRCUMSTANCES IS IT NECESSARY?}

This Part introduces the open access distribution tariff (OADT), a mechanism intended to more broadly spur the advancement of open networking, and makes the case for its necessity.

42. See ASPEN INST., supra note 5, at 5. In a different context, see Shara Tibken, How Samsung Might Actually Get Featuritis Under Control, CNET (Mar. 15, 2013) (noting that "cramming unnecessary capabilities into products can make them confusing and difficult to use").

43. Joseph P. Tomain, Traditionally-Structured Electric Utilities in a Distributed Generation World, 38 NOVA L. REV. 1, 3 (forthcoming 2014) (file with author) ("IOUs must change their business models in significant-if not dramatic-ways").

44. ASPEN INST., supra note 5 , at 6.

45. Eisen, supra note 4, at 21-24. 


\section{A. The Open Access Distribution Tariff}

The OADT would apply to the nation's electricity distribution system. "Distribution" is the final stage of moving electricity to consumers, which includes the local system of low-voltage lines, substations and transformers, and operations that provide service (such as billing and outage restoration systems). ${ }^{46}$ The OADT would provide that any person or entity would have open access to the distribution grid to buy or sell power on the same terms as any other person or entity. It has an appealing analogue in FERC's Order 888. That rule aimed to end the monopoly power of providers in the transmission network, which includes the high-voltage lines running from electricity generators to the distribution system, where electric companies then deliver it to consumers. ${ }^{47}$ Order 888 granted open access to the nation's transmission lines to all participants in the nation's wholesale power system on equal terms. Its specific terms required the nation's public utilities to file open access transmission tariffs (OATTs), under which they must offer transmission service on the same terms they provide themselves. ${ }^{48}$ Thus, it has resonance as a framework for defining the idea of open access to the distribution system.

At a minimum, the OADT would have attributes comparable to those of the OATT. First, it would establish a principle of open access to the smart electricity network. A justification for the OATT was that "it is important that the non-traditional generators of cheaper power be able to gain access to the transmission grid on a non-discriminatory open access basis." ${ }^{49}$ One central aspect of this (comparable to the Order 888 requirement that transmission providers create a level playing field for all resources) would be accurate price signaling and other terms, offered on a nondiscriminatory basis to all potential energy resource providers. ${ }^{50}$ Another aspect, intended to prevent undue discrimination, would be preemption of state efforts to preclude resources from entry to the network (such as onerous licensing requirements).

46. How Electricity Is Delivered To Customers, U.S. ENERGY INFO. ADMIN., http://www.eia.gov/energy explained/index.cfm?page=electricity_delivery.

47. Transmission, EDISON ELEC. INST., http:/www.eei.org/issuesandpolicy/transmission/Pages/ default.aspx.

48. FERC Order 888, supra note 3. This requirement is now codified in Non Discriminatory Open Access Transmission Tariff, 18 C.F.R $\$ 35.28$ (2013).

49. FERC Order 888, supra note 3 , at 21,550.

50. FERC Order 888, supra note 3, at 21,596. 
The OADT would also have a transparent information system, like the Open Access Same-Time Information System (OASIS) for transmission, ${ }^{51}$ designed to enable all actors on the network to locate distributed resources readily and easily. It might also establish network regulatory capabilities, vesting them either in a new organization (as Order 888 did with Independent System Operators (ISOs)) or a preexisting one. Finally, it might provide for the distribution-level analogue of stranded costs, ${ }^{52}$ compensating wires and infrastructure providers (utilities) for their transformation from monopolists to common carriers. ${ }^{53}$

This framework is an introduction to extending Order 888's terms and logic to the distribution level, and as such, is only the beginning of the OADT development process. There are formidable design and preemption issues. If anyone anywhere could sell electricity to the grid, a large number of state and federal laws would have to change. For example, wholesale markets limit participation in markets for certain resources to participants of a certain size. The OADT would eliminate these limits. Reliability and frequency regulation would pose considerable challenges and the OADT would have to address them. An OADT would have to interact with, and potentially preempt state laws, such as laws granting monopoly franchises to incumbent utilities for sales to consumers within defined territories, ${ }^{54}$ net metering laws (which specify conditions under which consumers can make the electric meter

51. The FERC established the Open Access Same-Time Information System (OASIS) in Open Access Same-Time Information System (Formerly Real-Time Information Networks) and Standards of Conduct, 61 Fed. Reg. 21,737 (Apr. 24, 1996) (to be codified at 18 C.F.R. pt. 37).

52. Stranded costs included utilities' investments in power plants and other expenses (such as costs of energy efficiency programs and fixed power supply contracts) that utilities made in a regulated environment, but which would be economically obsolete in the newly restructured environment by hampering their ability to compete with new power suppliers. William J. Baumol \& J. Gregory Sidak, Stranded Costs, 18 HARV. J.L. \& PUB. POL'Y 835 (1995). Scholars made forceful arguments that utilities should recover these stranded costs due to sweeping changes in the nature of the regulatory bargain under which they had previously operated. See, e.g., J. Gregory Sidak \& Daniel F. Spulber, Deregulatory Takings and Breach of the Regulatory Contract, 71 N.Y.U. L. REV. 851 (1996). Others disagreed. See, e.g., Bernard Black, A Proposal for Implementing Retail Competition in the Electricity Industry, 7 ELEC. J. 58, 58 (calling on regulators to "ignore sunk costs"). Eventually, states developed mechanisms for recovery of utilities' stranded costs, often involving fees charged to electric customers. See, e.g., Virginia Restructuring Suspended, U.S. ENERGY INFO. ADMIN., http://www.eia.gov/electricity/ policies/restructuring/virginia.html (last visited May 20, 2014) (discussing the imposition of a "wires charge" in 1999).

53. ASPEN INST., supra note 5, at 11-12 ("As Joel Eisen, Professor of Law at University of Richmond Law School, explained, there should be some mechanism that provides 'fair compensation for the common-carrier function that the distribution utilities provide' that also makes open access possible.").

54. Infra notes 62-66. 
spin backwards and sell excess power to the grid), laws requiring those providing sites for energy facilities to obtain Certificates of Public Convenience and Necessity (CPCNs) from state PUCs, and state and local laws governing the siting of energy facilities. So for the moment, consider this OADT concept for illustrative purposes only.

\section{B. Is an OADT Necessary?}

The remedy that FERC would seek - the OADT-relies on a tested method of providing open access that utilities are already familiar with from the OATT context. Returning to the question with which this Part began, a threshold concern is whether an OADT will ever be necessary. One reason it is needed stems from the ability of incumbent utilities to oppose change.

An open network promotes new applications and transformative innovation that may unlock latent consumer demand and lead to interactivity on the electric grid. ${ }^{55}$ Resisting this open access is a traditional response of incumbents. ${ }^{56}$ Here, the incumbents are major investor-owned utilities that can be expected to bring powerful opposition to opening the electricity distribution system. It is helpful to understand some of the forces animating this opposition. As the Edison Electric Institute (EEI, the trade association for major investorowned utilities) has discussed in a widely cited report, ${ }^{57}$ utilities fear continued erosion of their market share. Specifically, the EEI report indicates that a combination of disruptive technologies and the emergence of networking could create a death spiral. As utilities lose customers to other electricity providers, they would become unprofitable and would have to raise rates on their remaining customers. This would drive further declines in market share and profits.

This fear of losing market share will prompt a backlash against open access. Indeed, incumbent utilities already cite the substantial operational, legal, and financial barriers to networking as reasons to oppose it. For example, an open electric grid in which anyone can put power in or take power out would be difficult to keep in balance. Adequate and careful controls would be necessary to maintain system reliability and security (including the grid's resistance to

55. See generally ASPEN INST., supra note 5 (discussing numerous ongoing developments, all of which might culminate in the emergence of a smart electricity network).

56. Sidak \& Spulber, supra note 52, at 873 (noting that "[o]pposition to new entry, of course, is a predictable response among incumbent firms in any industry").

57. KIND, supra note 27 , at 19. 
cyber-attacks ${ }^{58}$ ). One context in which utilities are already making these and other arguments to resist entities that seek to introduce power onto the electric grid involves net metering. Net metering is a system under which distributed generators sell their excess generation back to the grid. ${ }^{59}$ In net metering regimes, renewable energy generation systems owners' electric meters "run backwards" to give them credit for any electricity that they put back on the electricity grid. Under the typical state net metering law, all electric utilities must make net metering available to eligible customers until a statewide cap is reached, ${ }^{60}$ and state PUCs generally have regulations that determine what types of systems get net metering credit and how owners are credited on their bills by utilities. The typical law permits a wide variety of ownership structures, including outright ownership and third-party ownership through leases and power purchase agreements, permitting business model experimentation. ${ }^{61}$

Incumbent utilities have begun to fight net metering. ${ }^{62}$ In some states, they have argued against expansion of programs beyond modest initial sizes, ${ }^{63}$ arguing (among other claims) that net metering unfairly subsidizes renewable energy generators at the expense of other ratepayers. ${ }^{64}$ In other states, utilities have successfully spent millions of dollars lobbying state legislatures to impose fees on solar systems to address the perceived cross-subsidization of net

58. See, e.g., U.S. GOV'T ACCOUNTABILITY OFF., CYBERSECURITY: CHALLENGES IN SECURING THE ELECTRICITY GRID 9-10 (2012).

59. See, e.g., Net Metering, SOLAR ENERGY INDUS. ASS'N, http://www.seia.org/policy/distributedsolar/net-metering (last visited Feb. 7, 2014).

60. Policies for Compensating Behind-the-Meter Generation Vary by State, U.S. ENERGY INFO. ADMIN. (May 9, 2012), http://www.eia.gov/todayinenergy/detail.cfm?id=6190. Califomia, for example, increased its cap in 2012 to five percent of noncoincident peak load, or approximately 5.2 gigawatts. See CAL. PUB. UTILS. COMM'N, DEC. 12-05-036, DECISION REgARDING CALCULATION OFTHE NET ENERGY METERING CAP 1 (2012).

61. See CHELSEA BARNES, AgGREgATE NET METERING: OpPORTUNITIES For LOCAL GOVERNMENTS 7 (2013), available at http:/www.icleiusa.org/action-center/aggregate-netmetering-opportunities-for-local-governments.

62. Mark Chediak, Christopher Martin \& Ken Wells, Utilities Feeling Rooftop Solar Heat Start Figbting Back, BLOOMBERG, Dec. 26, 2013, http:/www.bloomberg:com/news/2013-12-26/utilitiesfeeling-rooftop-solar-heat-start-fighting-back.html.

63. See Devon Swezey, PUCs: On the Front Line of the Brewing Net Metering Battle, ENERGY COLLECTIVE (Aug. 2, 2013), http://theenergycollective.com/devonswezey/256576/pucs-frontline-brewing-net-metering-battle (noting that as net metering grows, "more and more utilities have openly opposed further expansion in the amount they are required to accommodate").

64. Jennifer Van Burkleo, When Mom Said Life Isn't Fair,' She Meant Net Metering, POWERGRID INT'L (Aug. 1, 2012), available at http://www.elp.com/articles/powergrid_international/print/ volume-17/issue-8/features/when-mom-said-life-isnt-fair-she-meant-net-metering.html ("By not paying their fair share of these charges, net metering customers would make it necessary for their utility to raise rates to make up the shortfall, which would shift the burden of these costs onto customers without net metering." (quoting Rick Tempchin, executive director of retail energy services at the Edison Electric Institute)). 
metering. ${ }^{65}$ Nor are utilities' efforts limited to combating net metering. In Iowa, an incumbent utility petitioned the state's Utility Board to have a solar provider declared a public utility subject to state regulation and in violation of state law awarding an exclusive franchise to the utility; the Board agreed but a state district court reversed that finding. The Board's appeal to the state's Supreme Court is pending. ${ }^{66}$

The fights over expanding net metering and the growth of solar systems suggests it would be especially important to restrict the utilities' ability to hamper open access, because they may prevent networked applications from developing. Just as the ability to access library collections in the early $1990 \mathrm{~s}$ hinted at the Internet's transformative potential, ${ }^{67}$ many applications that would use a network are only in the pilot stage. For example, Smart Grid demonstration projects ongoing around the world aim to serve as test beds for connected technologies. ${ }^{68}$ Scholars and policymakers are only beginning to address privacy ${ }^{69}$ and data concerns that will affect development of networking applications, including key questions about who owns and controls electricity usage data, for what purposes this data can be used, and how to encourage entrepreneurs to find new and innovative uses for the data. ${ }^{70}$

65. A 2013 Arizona law imposes a fixed charge of 70 cents per kilowatt of system capacity (about $\$ 5 /$ month for a typical system) on solar systems. Diane Cardwell, Compromise in Arizona Defers a Solar Power Fight, N.Y. TiMEs, Nov. 15, 2013 (noting that the utilities sought a $\$ 40-\$ 50$ per month charge). Similarly, a 2014 Oklahoma law will impose a fixed charge, with the amount yet to be determined. Kiley Kroh, Oklaboma Will Charge Customers Who Install Their Own Solar Panels, CLIMATE PROGRESS, Apr. 16, 2014, http://thinkprogress.org/climate/2014/04/16/3427392/oklahoma-fee-solar-wind. See generally Gabe Elsner, The Campaign Against Net Metering: ALEC and Utility Interests' Next Attack on Clean Energy Surfaces in Arizona, ENERGY \& POL'Y INST., Nov. 18, 2013 http://www.energyandpolicy.org/the_campaign_against_net_metering_alec_and_utili ty_interests_next_attack_on_clean_energy_surfaces_in_arizona (arguing that the efforts by utilities and the American Legislative Executive Council are a coordinated campaign to "weaken net metering policies").

66. SZ Enterprises, LLC v. Iowa Utilities Board, No. 13-0642 (Ia. S.Ct. Jan. 22, 2014); see Grant Rodgers, Supreme Court bears Dubuque solar power case, DES MOINES REGISTER, Jan. 22, 2014 (discussing oral argument in the case).

67. William Y. Arms, The 1990s: The Formative Years of Digital Libraries, CORNELL, http:/www.cs.cornell.edu/wya/papers/LibHiTech-2012.pdf (last visited March 22, 2014).

68. See, e.g., David Biello, Will You or the Grid Control Your Electric Car?, ScI. AM. (June 18, 2013), http://www.scientificamerican.com/article/remote-control-of-electric-cars (discussing the Mueller neighborhood demonstration project in Austin, Texas, of the Pecan Street Project); Jeju Smart Grid Test-Bed, JEJU, http://smartgrid.jeju.go.kr/eng/contents/index.php?mid=0202 (last visited Feb. 21, 2014) (website of Korean Smart Grid demonstration project involving over 100 companies).

69. See, e.g., Sonia K. McNeil, Privacy and the Modern Grid, 25 HARV.J.L. \& TECH. 199 (2011); Cheryl Dancey Balough, Privacy Implications of Smart Meters, 86 CHI.KENT L. REV. 161 (2011).

70. See, e.g., GREEN BUTTON, http://www.greenbuttondata.org/greenabout.html (last visited Jan. 22, 2014) (claiming that "electricity customers should be able to securely download their own easy-to 
This leads to two different conclusions about the need for an OADT. First, as noted above, we have to establish a network in the absence of consumer demand and rely on the evolving infrastructure to stimulate demand. Without openness, however, few developers will push for a network. Furthermore, the utilities are not nimble innovators and are not taking the lead to promote networking. In addition, there is no constituency with the means to advocate for it against utility resistance, as participants are not focusing on creating an open multidirectional network at the distribution level. ${ }^{71}$

As we make our way forward, we will make fundamental decisions about networking. Many utilities have already demonstrated that they do not see the purpose of smart meters (the most visible building block of networking infrastructure being deployed today) as empowering networking applications. In the near term, they can make decisions that establish fundamental choices about consumer preferences and lead to a series of closed proprietary networks. For example, the interoperability standards specify that the gateway between a consumer and the utility is an "Energy Services Interface" that could take a variety of different forms (programmable thermostat, iPad, etc.). ${ }^{72}$ Without intervention to create a right of open access, utilities can control this gateway.

Finally, the regulatory landscape for electric utilities poses a considerable barrier to establishing a national network. While electricity moves nationally, state PUCs retain substantial regulatory authority over it. FERC regulates wholesale electricity transactions and electric transmission in interstate commerce, but the states retain authority over such matters as licensing and siting of new power plants and transmission lines. This geographic mismatch between electricity's flow and its regulation has led numerous scholars to criticize the existing regulatory framework, and to suggest innovative federal solutions to such matters as transmission siting and standards for the Smart Grid to promote network efficiencies. ${ }^{73}$ Some of these solutions, of course, are only on the

understand energy usage information from their utility or electricity supplier," and that allowing this information to become available could spur entrepreneurs to create "innovative applications that can help consumers make the most of their energy usage information").

71. See Joel B. Eisen, Residential Renewable Energy: By Whom?, 31 UTAH ENVTL. L. ReV. 339 (2011) (discussing distribution-level barriers to more widespread deployment of renewable energy).

72. CUSTOMER ENERGY SERVICES INTERFACE WHITE PAPER: SMARTGRID INTEROPERABILITY PANEL B2G/I2G/H2G DOMAIN EXPERT WORKING GROUPS (Dave Hardin ed., 2011), available at http://www.gridwiseac.org/ pdfs/forum_papers11/hardin_paper_gi11.pdf (discussing the Energy Services Interface concept and its adoption in the National Institute of Standards and Technology Framework); see Eisen, supra note 4, 21-24.

73. See Ashira Pelman Ostrow, Grid Governance: The Role of a National Network Coordinator, CARDOZO L. REV. (forthcoming 2014); Eisen, supra note 4; Alexandra B. Klass \& Elizabeth J. Wilson, 
drawing board, and the presence of fifty state PUCs in the regulatory landscape makes the idea of establishing a national smart electricity network a daunting proposition.

For all of these reasons, it is not likely that evolutionary technologyprompting public policies will eventually accrete to the fundamental equivalent of an open access principle. Thus, there is a need for an OADT, and two central questions present themselves. At what point should we establish the principle of open access, and what features of technology and legal development would indicate that the time has come for open access?

\section{MODELS FOR OPEN ACCESS: LESSONS FOR POLICY EVOLUTION}

To address these issues, this Part examines three models drawn from different industries that have fundamentally changed in character in the past quarter-century, resulting in the formation of new networks (telecommunications), fundamental alterations to existing ones (wholesale energy markets), or fundamental changes to the regulation of interactions in existing networks (finance).

Any direct parallel is difficult, of course, because any examination of an industry that transformed is necessarily retrospective after change took place. As the smart electricity network evolves, we may not know where we are on the policy path toward open access. But while no analogue is directly representative of the likely transition, these models offer some potential lessons about the timing and other preconditions necessary for revolutionary change.

The discussion focuses on two parameters: (1) timing-what to look for in determining whether timing of the transformation is appropriate for open access (and what conditions might make open access more desirable to industry actors), and (2) regulatory prerequisites - which are necessary in the near term (given that open access is proposed for some future date). Finally, the discussion analyzes risks involved in relying on any one particular combination of timing and regulatory evolution, including federalism concerns.

\section{A. The Telecommunications Model}

The industry transformation perhaps cited most often as the best model for the electric grid's potential to morph into a smart electricity network is the

Interstate Transmission Challenges for Renewable Energy: A Federalism Mismatch, 65 VAND. L. REV. 1801 (2012). 
modern revolution in telecommunications, specifically in telephone service. ${ }^{74}$ The open access provisions of the landmark Telecommunications Act of $1996(1996 \mathrm{Act})^{75}$ ended the monopoly of local telephone service and accelerated the transformation to a robust modern communications network. Thus, perhaps the most intriguing lesson from the telecommunications model is that with the right policy prescription implemented at the right societal moment, changes in the electricity sector can be just as dramatic and rapid as they were in the telephone sector.

\section{Appeal of the Telecommunications Model}

This model is appealing for numerous reasons. First, it involves open access to local distribution lines, as the 1996 Act contained specific provisions designed to open telephone lines to competition. Second, telecommunications, like electricity, involves a network industry traditionally regulated as a public utility from the early years of the twentieth century. ${ }^{76}$ Third, telecommunications regulatory evolution involved a change to new paradigms of governmental involvement, following decades of traditional regulation. Finally, the evolution of telephony features the emergence of new actors and new industries. Its story is one of a displacement of a stodgy, old technology (landlines) by an upstart, smaller, more nimble one (wireless) that literally circumvented the need for much of the existing infrastructure, resulted in creation of a new network, and put economic pressure on existing industry actors. ${ }^{77}$

The 1996 Act opened distribution lines, leading to competition in the provision of local telephone service and to disruption of an existing industry structure dominated by natural monopolies. That open access was to physical copper telephone wires, a close analogue to the potential opening of electricity distribution wires. Similarly, encouraging competition in the electricity distribution sector by opening the distribution wires could disrupt natural monopolies. While different types of entities (including municipal utilities and

74. While the Telecommunications Act of 1996 (1996 Act) made changes in other areas of communications law and policy (for example, overhauling the federal rules regarding television broadcast ownership), see The Telecommunications Act of 1996, NTIA.GOV, http://www.ntiadoc.gov/legacy/otiahome/top/publicationmedia/newsltr/telcom_act.htm), this Article focuses on the central changes made to telephone law and policy.

75. Pub. L. No. 104-104, 110 Stat. 56 (1996).

76. Daniel F. Spulber, Deregulating Telecommunications, 12 YALEJ. ON REG. 25, 28 (1995).

77. See generally GREGORY L. ROSSTON, STAN. INST. FOR ECON. POL'Y RES., THE RELATIONSHIP BETWEEN TECHNOLOGICAL AND REgULATORY CHANGE IN THE COMMUNICATIONS INDUSTRY (2012), available at http//siepr.stanford.edu/?q=/system/files/shared/pubs/papers/pdf/11020.pdf (discussing the evolution of the wireless telephone industry). 
cooperatives) deliver electricity, the nation's 243 investor-owned utilities continue to distribute 75 percent of the nation's electricity. ${ }^{78}$ Open access to distribution lines could reduce that share, perhaps dramatically.

Like the electricity industry, the telecommunications sector is ubiquitous. By one estimate, the 1996 Act was "said to affect as much as one-sixth of the American economy." ${ }^{\text {" T9 }}$ Thus, as one scholar noted nearly twenty years ago, the "lessons from the telecommunications industry are applicable to other network industries such as electric power." ${ }^{\prime \prime 0}$ Moreover, evolution of governmental involvement in telecommunications did not spell the end of regulation but its continuation. Regulation remains in place today in various parts of the telecommunications sector, albeit in a different form. ${ }^{81}$ That transformation is significant. For example, Professors Joseph Kearney and Thomas Merrill's seminal 1998 article, "The Great Transformation of Regulated Industries Law," discusses the evolution of regulation from focusing on regulating the cost of service to protecting consumers and encouraging entry into the industry, citing both telecommunications and electricity as examples.

The 1996 Act was a major watershed in telecommunications law and policy, ${ }^{82}$ and it allocated numerous new regulatory duties to federal, state, and local agencies. The focus of telecommunications regulation has shifted in the direction that FERC might take with the OADT: promoting market-based transactions, with the regulator's role being to ensure the advancement of competition. ${ }^{83}$ Like the shift in telecommunications regulation, the OADT would allow regulation to evolve and accompany the rapidity of technological change, which has been a hallmark of the telecommunications industry. ${ }^{84}$

Several aspects of the rapid change in telephony technologies are worth noting, as they are comparable to the technological evolution some expect in

78. See Electricity Data, U.S. ENERGY INFO. ADMIN., http://www.eia.gov/electricity/data.cfm (last visited Feb. 11, 2014).

79. Joseph D. Kearney \& Thomas W. Merrill, The Great Transformation of Regulated Industries Law, 98 COLUM. L. REV. 1323, 1326 (1998).

80. Spulber, supra note 76 , at 28.

81. See Kearney \&Merrill, supra note 79, at 1323.

82. Joseph D. Kearney, From the Fall of the Bell System to the Telecommunications Act: Regulation of Telecommunications Under Judge Greene, 50 HASTINGS L.J. 1395, 1396 (1999) (terming the 1996 Act "the most important transformative event in telecommunications law since January 1, 1984").

83. Kearney \& Merrill, supra note 79, at 1361 (noting that in this new paradigm, "the regulator is expected to intervene only when there is some reason to conclude that a regime of marketbased transactions will not suffice to advance competition, as where one firm in the industry owns a bottleneck facility that has natural monopoly characteristics").

84. See Nicholas Economides, The Telecommunications Act of 1996 and Its Impact, 11 JAPAN \& WORLD ECON. 455, 456 (1999) (observing that in telecommunications, "[r]apid technological change has always been the original cause of regulatory change"). 
the electric grid. The displacement of landline telephones by wireless phones is a compelling example of a near-comprehensive replacement of "dumb" technology by "smart" upgrades, with the "dumb" system still in place but receding quickly into the dustbin of history in the years after "business leaders agreed that mobility was superior to fixed line telephony and that the internet beat any other form of transmitting data." 85 The new telephone products and services have functions and capabilities different from and, in some cases, well beyond and more attractive than, those of the existing network (mobile phones can do more than landlines). ${ }^{86}$ This is also consistent with the literature about disruptive technologies. New firms, not incumbents, are responsible for transformative change. ${ }^{87}$

To many, then, the "dumb" electricity industry resembles the telecommunications industry before the $1996 \mathrm{Act},{ }^{88}$ which makes the telecommunications model of transformation worthy of further scrutiny. But the 1996 Act's open access provisions applied to entrants into the landline local telephone market, not wireless telephony. Therefore, one aspect of the "dumb to smart" narrative requires some rethinking. The smart technologies we know today (wireless smartphones and applications) were not the subject of the 1996 Act's open access provisions. As discussed more fully below, however, a closer parallel to the proposed design and features of the OADT would be harder to imagine. The 1996 Act's provisions required open access on a nondiscriminatory basis, facilitated by interconnection at just and reasonable rates. This makes the 1996 Act deserving of closer scrutiny as a possible exemplar for transformation of the electric grid.

\section{Regulatory Evolution and Effects of the 1996 Act}

The 1996 Act's grand bargain resulted in an open access provision that allowed for dramatic change in the telephone network. Understanding this provision requires a journey into history and examination of several decades of legal twists and turns in the telephone industry. An important part of this

\footnotetext{
85. ASPEN INST., supra note 5, at 7.

86. HENDRICKS \& JAMES, supra note 26, at 14 (observing that we have "a telecommunications system able to perform its original objectives-providing affordable and universal service-far better while branching out to meet new objectives of mobility, interoperability, and data integration").

87. See e.g., Clayton M. Christensen, The Innovator's DLemma: When NeW TECHNOLOGIES CAUSE GREAT FiRMS TO FAIL 14-19(1997).

88. See generally HENDRICKS \& JAMES, supra note 26 (observing the many opportunities for the electricity industry to transform in ways similar to the telecommunications sector).
} 
history is United States $v . A T E T{ }^{89}$ the major antitrust suit brought by the federal government in 1974 (after separate litigation dating back to 1949). ${ }^{90}$ That lawsuit charged AT\&T, which at that time led the Bell System and provided telephone service to most of the United States, with (among other unlawful activities) illegally monopolizing the long-distance telephone market. ${ }^{91}$ The landmark 1982 Modification of Final Judgment (MFJ) consent decree settled this litigation, ${ }^{92}$ with core provisions that mandated a breakup of the Bell System monopoly and imposed prospective restrictions on conduct by the newly formed companies. ${ }^{93}$ AT\&T agreed to divest itself of all ownership and control of seven regional Bell operating companies (RBOCs), ${ }^{94}$ each of which included local telephone companies that were part of AT\&T before the breakup. ${ }^{95}$ RBOCs remained regulated monopolies, each with an exclusive franchise in its region. ${ }^{96}$

This remedy reflected the federal government's prevailing contention that local telephone service was a natural monopoly, while competition was possible in long-distance service. In the early 1980 s, AT\&T provided nearly all of the nation's long-distance telephone service. ${ }^{97}$ Long-distance service became competitive because of the use of microwave towers to provide long-haul carriage of telephone calls. Microwave transmission was a major breakthrough that created the possibility of competition. But it had no large economies of scale and therefore did not threaten to become a natural monopoly itself. In the local telephone market, there was no viable competition. Dial-up Internet access was just beginning, ${ }^{98}$ and (as discussed in greater detail below) mobile phones were not yet widely available. ${ }^{99}$

89. 552 F. Supp. 131 (D.D.C. 1982).

90. Id. In his decision, Judge Greene found the proposed consent decree to be in the public interest and provided a lengthy description of the history of the AT\&T antitrust litigation. Id.

91. Id. at 139

92. Id. at $140-41$

93. Id. at 141 ; see also Kearney, supra note 82 , at 1410.

94. ATST Co., 552 F. Supp. at 141.

95. Id. at 141

96. Id. at 142

97. In the early 1980s, AT\&CT provided about three-quarters of the nation's local telephone service and almost all interstate long-distance service. FED. COMMC'NS COMM'N, TRENDS IN TELEPHONE SERVICE 1 (2000) [hereinafter FCC], available at http://transition.fcc.gov/Bureaus/Common Carrier/Reports/FCC-State_Link/IAD/trend100.pdf.

98. For example, the first Internet Service Provider, The World, did not come into existence until 1989. See THE WORLD, http://world.std.com.

99. See FCC, supra note 97, at 2-3. In December 1984 there were thirty-two cellular telephone systems with 91,600 subscribers. $I d$. 
The MFJ imposed this so-called line of business restrictions on the RBOCs. ${ }^{100}$ It allowed them to market telecommunications services within designated local access and transport areas (LATAs), ${ }^{101}$ but barred them from offering services that crossed LATA boundaries. Specifically, the RBOCs were prohibited, "directly or through any affiliated enterprise, from providing long-distance service, manufacturing or providing telecommunications equipment or customer premises equipment, or providing so-called information services." ${ }^{102}$ The reason for this was that "each RBOC was a monopolist in its own region," and the prevailing view was that if RBOCs provided longdistance service, they could compete unfairly against new entrants in the long-distance business. ${ }^{103}$

The subsequent period between the breakup of the Bell System in 1984 after the MFJ and the enactment of the 1996 Act is also important in understanding the 1996 Act's open access provisions. ${ }^{104}$ In the intervening years, the distinction between local and long-distance telephone calls had evaporated due to dramatic decreases in the cost of transmitting calls over long distance. ${ }^{105}$ By 1996, this led to widespread calls to modify or eliminate the MFJ's restrictions. ${ }^{106}$ The 1996 Act's grand bargain between competing long-distance and local telephone companies erased the legal boundaries between the local telephone and long-distance markets, removing the MFJ line of business restrictions that had prevented the RBOCs from offering long-distance telephone service. ${ }^{107}$ Specifically, the 1996 Act permitted each RBOC to provide long-distance services outside of its monopoly service region. ${ }^{108}$ In return, the RBOCs agreed to open their local networks to competitors. ${ }^{109}$

Section 251 of the 1996 Act was the central open access provision. ${ }^{110}$ It required incumbent local exchange carriers (ILECs) - the RBOCs - to make their facilities available to their competitors, known as competing local exchange carriers (CLECs). ${ }^{111}$ Under this section, ILECs were required to offer their competitors

100. ATछT Co., 552 F. Supp. at $141,178$.

101. Id.

102. Kearney, supra note 82, at 1413-14 (quoting Section II(D) of the MFJ).

103. Economides, supra note 84, at 468.

104. Kearney, supra note 82, at 1397.

105. RosSTON, supra note 77 , at 12 n.34

106. See Spulber, supra note 76, at 27.

107. Telecommunications Act of $1996 \S 101,47$ U.S.C. $\$ 251$ (2006).

108. Id.

109. Id.; see also Kearney \& Merrill, supra note 79, at 1352 (noting that the 1996 Act "links RBOC entry into the long-distance market to the development of competition in their local markets").

110. 47 U.S.C. $\$ 251$.

111. Id. 
interconnection to their networks "equal in quality to that provided by the local exchange carrier to itself or to any subsidiary, affiliate, or any other party to which the carrier provides interconnection." 112 Furthermore, they were required to offer "rates, terms, and conditions that are just, reasonable, and nondiscriminatory."113 Section 251 introduced a concept of unbundled access. It required ILECs to offer "nondiscriminatory access to network elements on an unbundled basis," with access taking place "at any technically feasible point on rates, terms, and conditions that are just, reasonable, and nondiscriminatory." ${ }^{114}$ Section 252(d) empowered state public utility commissions to set "just and reasonable rate[s] for interconnection." 115 Section 253 removed barriers to entry to local telephone service, providing that "[n]o State or local statute or regulation, or other State or local legal requirement, may prohibit or have the effect of prohibiting the ability of any entity to provide any interstate or intrastate telecommunications service."116

Eventually, observers credited the 1996 Act with promoting the expansive growth of wireless telephone communications entities and technologies. As one commentator stated, "In parallel [with changes in long distance], wireless telephony grew to great success."117 In 1996, however, the competitive landscape for local telephone service looked far different than it does today. America was still a nation of landline phones, and many did not foresee that mobile phones would displace landlines so completely. A rapidly growing number of Americans had mobile phones, ${ }^{118}$ but the ubiquity of wireless was years away.

At the time, no single best technology existed to replace stationary telephone equipment. Indeed, it was not clear which of a number of competing technologies would emerge as the primary competitor to landline phones. Two different wireless technologies - Personal Communications Service (PCS) ${ }^{119}$ and the conventional cellular technology now familiar to billions across the globe-were poised for growth. There was no such thing as a national cellular network. Years before, the FCC had allocated two licenses in each metropolitan area to would-be wireless

112. Id.; see also Economides, supra note 84, at 11.

113. 47 U.S.C. $\$ 251$; see also Hannibal Travis, Wi-Fi Everywbere: Universal Broadband Access as Antitrust and Telecommunications Policy, 55 AM. U. L. REV. 1697, 1726 (2006) (discussing this provision).

114. 47 U.S.C. $\$ 251$ (c)(3) (2006).

115. 47 U.S.C. $\$ 252(\mathrm{~d})(1)$.

116. 47 U.S.C. $\$ 253(\mathrm{a})$

117. Economides, supra note 84 , at 1.

118. See FCC, supra note 97 , at 2-3 (showing that there were 44,042,992 cellular telephone subscribers in December 1996 in contrast to 681,825 subscribers a decade earlier).

119. Spulber, supra note 76, at 44 ("Personal Communications Service (PCS) is the next major advance in cellular telephone service. It is similar to conventional cellular service, except it is higher frequency, all digital."). 
companies. One license went to an existing wireline company, and one went to a wireless entrant. ${ }^{120}$ But the infrastructure for seamless regional calls did not exist yet, and the familiar cell towers were not in place in most of the nation. Using fiber optic cable for phone calls (what we now know as voice over IP or VoIP) was in its infancy and did not merit any mention in the 1996 Act. ${ }^{121}$

One interesting technology emerging at the time deserves mention because it has a parallel in today's electric grid. So-called competitive access providers (CAPs) allowed business and commercial entities to lay their own telephone wires and make calls at their own premises. ${ }^{122}$ If this sounds familiar, one should note the same idea is sprouting up in today's microgrids ${ }^{123}$ that selfgenerate electricity in islands without connections to the electric grid. Some CAPs began to offer local telephone calling services to a broader range of customers, ${ }^{124}$ and by virtue of this expansion became CLECs that took advantage of the 1996 Act's open access provisions. ${ }^{125}$

These technologies seemed promising at the time. The combination of potential and uncertainty make law review articles from the mid-1990s seem alternately prescient in their predictions of a wireless future and quaint in their hedging of bets on which technology would survive. For example, consider this understatement from 1996: "[C]onsumers will still be wary of replacing the wired telephone and the local access provider that has served them for over a decade." ${ }^{126}$

Separate incentives for wireless promoted its development. The 1996 Act encouraged wireless telephony through a number of provisions. The FCC did not acquire the power to preempt state and local laws about siting, but the 1996 Act limited state regulation. For example, state and local governments were limited in their ability to delay applications for cell tower siting. ${ }^{127}$

120. Rosston, supra note 77 , at 5.

121. See Economides, supra note 84, at 41 ("The Telecommunications Act of 1996 did not legislate any framework for the most revolutionary of all current innovations in telecommunications, Internet telephony, or more precisely Internet Protocol ("IP") telephony.").

122. "In the 1980 s, competitive access providers (CAPs) began to market to business customers access services provided over CAPs wired networks." FCC, supra note 97, at 9-1; see also Spulber, supra note 76 , at $40,44$.

123. See supra notes $19-20$ and accompanying text.

124. See FCC, supra note 97, at 9-1.

125. Id.

126. Lisa M. Warner, Wireless Technologies Creating Competition in the Local Exchange Market: How Will Local Exchange Carriers Compete?, 4 COMMLAW CONSPECTUS 51, 52 (1996).

127. Telecommunications Act of 1996, Pub. L. No. 104-104, § 704, 110 Stat. 56, 151 (codified at 47 U.S.C. $\$ 332(\mathrm{c})(7))$. This hybrid was the first federal statutory provision that "empowers local governments to make primary siting decisions, subject to federal constraints on the decisionmaking process." Ashira P. Ostrow, Process Preemption in Federal Siting Regimes, 48 
This provision promoted dramatic growth in cell towers but has sparked much controversy since $1996 .{ }^{128}$

\section{Lessons for a Smart Electricity Network}

The lengthy history of evolution in telephone regulation, stretching back for decades, has much to offer as a potential model for the transition to a smart electricity network.

\section{a. Signifiers That a Transition to Open Access Is Possible}

With respect to the first parameter-signifiers that a transition to open access is possible (and will therefore garner support) - the first lesson comes from the MFJ and its litigation backdrop. Without an existing, pervasive legal culture promoting deregulation (exemplified by the Bell System breakup despite the regulations that remained in place thereafter for over a decade), the open access provisions of the 1996 Act would not have been possible. This has enormous implications for using the telephone industry as a model for transitioning to the smart electricity network. Simply put, the telephone industry had begun ending the domination of vertically integrated monopolists. The monopoly over the market for comprehensive telephone service had ended, and then, a decade later, the distribution market (local telephone service) opened.

Another signifier stems from the central feature of the 1996 Act's grand bargain. Bargainers on all sides believed there were lucrative business opportunities to be gained from open access. Political consensus was possible because numerous constituencies thought it was in their best interest to support reform of the telecommunications industry. ${ }^{129}$ This allowed a political compromise. Congress could appear balanced ${ }^{130}$ in extending a market opportunity to the

HARV. J. ON LEGIS. 289, 289 (2011). Professor Ostrow terms this use of a federal statute to compel a local authority to site nationally important infrastructure "process preemption." Id.

128. A substantial body of law exists that interprets this provision, and describing it in detail is beyond the scope of this Article. See, e.g., City of Arlington v. FCC., 133 S. Ct. 1863 (2013) (extending Chevron deference to a FCC declaratory ruling on the provision).

129. See HENDRICKS \& JAMES, supra note 26, at 14 ("All parties-long distance carriers, local phone companies, wireless and data providers, cable companies, and emerging Internet technologies - needed clearer market rules in the form of federal policy. The emergence of a coherent industry voice in favor of policies to structure improved market rules set the stage for compromise and bipartisan action.")

130. Economides, supra note 84, at 9 ("The great success of competition in long distance allowed US Congress to appear 'balanced' in the Telecommunications Act of 1996 by establishing 
RBOCs while still requiring them to offer open access to their distribution lines. Action to provide open access was easier because Congress was not required to act against the interest of an industry sector that wielded considerable political clout. Notably, the 1996 Act's grand bargain did not affect the RBOCs' ability to enter the wireless market. The RBOCs believed (wrongly, as it turned out ${ }^{131}$ ) the long-distance market was the plum. ${ }^{132}$

This required the erosion of natural monopoly as a precondition. As observers of the 1996 Act have noted, legal change is appropriate when the regulated industry no longer retains the character of a natural monopoly and barriers to entry are lower. ${ }^{133}$ This is particularly true in a network industry when entrants do not need to develop new network infrastructure, ${ }^{134}$ and the 1996 Act provides an excellent example of how this occurs. The grand bargain was possible because of the introduction of competition in long-distance service. In 1984, AT\&T's share of the nation's long-distance telephone traffic was 90.1 percent. In 1996, its share was 47.9 percent, and it continued to drop in the years after that. ${ }^{135}$ Also, the new technology (microwave transmission) that enabled AT\&T's competitors to enter the long-distance market had not, by itself, led to natural monopoly. ${ }^{136}$

In the electric grid, it may take years for a comparable market opportunity to more fully erode local distribution utilities' natural monopoly. Like microwave transmission of long-distance telephone service, one or more of the technologies that utilities fear will disrupt their business model (rooftop solar, distributed generation, microgrids, and demand response $)^{137}$ may create substantial supply and satisfy demand without depending on existing distribution lines. ${ }^{138}$ In turn, these technologies would enable firms to transform into via-

competition in local telephony, while allowing RBOCs into long distance after they meet certain conditions.").

131. See FCC, supra note 97, at 14-8 tbl.14.6 (showing year-over-year decreases in long distance rates and revenue).

132. See Economides, supra note 84, at 4 ("[T]he Act definitely overestimated the importance of ILECs' long distance entry as an incentive for ILECs to open their local markets to competition.”).

133. See Spulber, supra note 76 , at 47.

134. Seeid.

135. FCC, supra note 97 , at 11-6 tbl.11.3.

136. See id. at 11-7 tbl.11.4 (setting forth market shares of the competitors to AT\&T, including $\mathrm{MCI}$ and Sprint).

137. See generally KIND, supra note 27 (discussing disruptive challenges to the utility industry).

138. There is a critical distinction between telephony and electricity in the location of the market opportunity. In telephony, competition arose in the use of interlocal access and transport area (LATA) long distance, not the local lines subject to the open access provisions. In electricity, distributed energy resources would potentially bypass the very lines being opened. This 
ble competitors to distribution utilities. Today, however, it is hard to foresee which firms will succeed at doing that.

At some point in time it may appear that the natural monopoly is eroding. Following the logic of this model, it would be timely to open electricity distribution lines to promote the interests of new entrants if utilities would receive some tangible benefit. ${ }^{139}$ Economic or other incentives to electric distribution utilities to enter into specific markets might serve as a carrot to the stick of requiring them to open their local wires to competitors. The challenge is that, even with the recent dramatic progress, deployment of new technologies has proven elusive for the last several decades. If these technologies gain increased market share over the coming years or decades, that may prompt utilities to be more accepting of government-mandated open access.

In the future, one possible indication that this transformation has taken place (beyond advanced deployment of cutting-edge technologies) is suggested by the morphing in telephony of CAPs into CLECs before the enactment of the 1996 Act. These companies originally provided service to limited areas, without interconnection to the wider marketplace. Then, they began to offer service beyond their original limits, evolving their business model to expand their portfolio of products and services and becoming companies that intended to benefit from open access to local telephone lines. It is perhaps foreseeable in the electric grid that a similar growth and transformation of companies that appear narrowly focused may take place. For example, a demand response firm may learn enough about its customers that it undertakes to supply them with electricity. ${ }^{140}$ At that time, open access would appear to be more appropriate.

\section{b. Necessary Regulatory Prerequisites}

With respect to the second parameter - necessary regulatory prerequisites - it is worth noting that the opening of local telephone lines required numerous critical legal developments over the decades before the 1996 Act, all of which led to that statute. In addition to the litigation resulting in the breakup of the Bell System, federal agency and judicial support was instrumental in encouraging the new technologies that changed the telephone industry.

Article contends, however, that the important factor is the quid pro quo of comparability, not the precise location of the market opportunity.

139. See supra note 53 and accompanying text (discussing the potential for compensating utilities for stranded costs in the OADT).

140. For a discussion of demand response and its role in electricity markets, see Joel B. Eisen, $W$ bo Regulates the Smart Grid?: FERC's Authority Over Demand Response Compensation in Wholesale Electricity Markets, 4 SAN DIEGO J. CLIMATE \&ENERGY L. 69 (2012-2013). 
Specific types of support included regulatory authorization of new technologies, and judicial intervention to supervene barriers faced by new entrants, particularly in several different instances when those entrants needed access to existing networks.

A central example involved microwave transmission, the technology that disrupted long-distance telephone service. Without encouragement of this technology, the erosion of the natural monopoly in long-distance telephone service may never have occurred. The development of competition by companies using microwave technology with AT\&T's long-distance telephone service took numerous years and many legal developments, including decisions of the FCC and decisions by federal appeals courts. A brief summary of this history will necessarily omit many details but suffices to illustrate basic principles.

The first development promoting microwave systems was the FCC's 1959 Above $890^{141}$ decision, in which the Commission authorized companies to build their own private line microwave communications systems, using a dedicated portion of the radio spectrum above $890 \mathrm{MHz}^{142}$ This did not authorize companies to become common carriers over microwave systems. In 1964, however, Microwave Communications, Inc. (later MCI) filed an application with the FCC to construct a microwave transmission network to provide service between St. Louis and Chicago. ${ }^{143} \mathrm{MCI}$ proposed to handle the transmissions between microwave transmitters, leaving its customers to arrange for interconnection between MCl's equipment and the customers' own equipment. ${ }^{144}$ While MCI was making its application, the President's Task Force on Communication Policy issued a report, which contained a recommendation to allow so-called specialized common carriers (like $\mathrm{MCI}$, although the report did not name it) free access into the private line business. ${ }^{145}$

The MCI application posed a competitive threat to AT\&T in long-distance telephone transmission. As one book about telecommunications policy at the time puts it, "FCC officials were reluctant to grant this authorization because

\footnotetext{
141. 27 F.C.C. 359 (1959), recon. denied, 29 F.C.C. 825 (1960).

142. Id. at $362-63$.

143. See Applications of Microwave Commc'ns, Inc, 18 F.C.C.2d 953 (1969), recon. denied, 21 F.C.C.2d 190 (1970) (detailing MCl's application and approving it).

144. This aspect of the application is discussed in Bell Tel. Co. of Pa. v. FCC, 503 F.2d 1250, 1254 (3d Cir. 1974); see also PETER TEMIN WITH LOUIS GALAMBOS, THE FALL OF THE BELI SYSTEM: A STUDY IN PRICES AND POLITICS 50 (1987) (discussing this impact of this aspect of the application).

145. See Eugene V. Rostow, PREsident's TASK ForCE on COMMUNICATIONS POlicy: FINAL REPORT ch. 6, 22-23 (1968).
} 
it would put MCI in direct competition with AT\&T." ${ }^{46}$ After some delay, the FCC "[r]ecogniz[ed] the need to foster the commercial development of new technologies"147 and approved MCl's proposed service in 1969 by a $4-3$ vote. ${ }^{148}$

Following MCl's approval from the FCC, it and numerous other companies applied to the Commission for approval of private line services. This prompted the major decision in Specialized Common Carrier Services, ${ }^{149}$ in which the FCC set forth principles to govern applications of these new firms. ${ }^{150}$ This decision served as the basis for the Commission's later grants of facilities authorizations to carriers, including $\mathrm{MCI}$, to provide microwave communications services. ${ }^{151}$ In its rulemaking proposal and subsequent decision, the FCC stated that it was concerned with five basic issues, including "[w] hether as a general policy the public interest would be served by permitting the entry of new carriers in the specialized communications field; and if so, $\ldots[\mathrm{w}]$ hat is the appropriate means for local distribution of the proposed services?"152 The FCC concluded:

$[T]$ here is a public need and demand for the proposed facilities and services and for new and diverse sources of supply, competition in the specialized communications field is reasonably feasible, there are grounds for a reasonable expectation that new entry will have some beneficial effects, and there is no reason to anticipate that new entry would have any adverse impact on service to the public by existing carriers such as to outweigh the considerations supporting new entry. We further find and conclude that a general policy in favor of the entry of new carriers in the specialized communications field would serve the public interest, convenience, and necessity. ${ }^{153}$

146. Kimberly A. Zarkin \& Michael J. Zarkin, The Federal COMMUNications COMMISSION: FRONT LINE IN THE CULTURE AND REGULATION WARS 63 (2006).

147. Id. at 64

148. Microwave Commins, Inc., 18 F.C.C.2d at 967.

149. Specialized Common Carrier Servs. in the Domestic Pub. Point-to-Point Microwave Radio Serv., 29 F.C.C.2d 870 (1971), aff d sub nom. Wash. Utils. \& Transp. Comm'n v. FCC, 513 F.2d 1142 (9th Cir. 1975).

150. Id.

151. See 47 U.S.C. $\$ 214$ (2006).

152. Specialized Common Carrier Servs., 29 F.C.C.2d at 878 (quoting Specialized Common Carrier Servs. in the Domestic Pub. Point-to-Point Microwave Radio Serv., 24 F.C.C.2d 318, 327 (1970)); see also Bell Tel. Co. of Pa. v. FCC, 503 F.2d 1250, 1255 (3d Cir. 1974) (discussing the proposal and decision).

153. Specialized Common Carrier Servs., 29 F.C.C.2d at 920. 
Later, in its landmark series of three Execunet decisions, ${ }^{154}$ the D.C. Circuit returned to AT\&T's ongoing refusal to provide interconnections for the specialized carriers. As part of its earlier decision approving MCl's application, the FCC recognized that connecting to AT\&T's network might pose problems for MCl's customers. ${ }^{155}$ That had proven prescient. As Judge J. Skelly Wright wrote for the D.C. Circuit, "MCI has met with almost continuous resistance from AT\&T in its efforts to provide communications services." 156 $\mathrm{MCI}$ sought a cease and desist order against AT\&T and an affirmative order that AT\&T was required to provide any physical connections "essential" to the rendition of "all" the services which any of the specialized common carriers "presently or hereafter" are authorized to offer. ${ }^{157}$ The FCC rejected this request for MCI's Execunet service, ${ }^{158}$ but the D.C. Circuit reversed the Commission. ${ }^{159}$ As one observer notes, by requiring AT\&T to interconnect with MCl's service, the Execunet II decision "was historic in that it had the effect of casting aside the decades-old AT\&T monopoly in long distance telephone service and forcing the FCC to open the door to competition." 160

Without another landmark FCC decision, the principle of interconnection would not have been possible. In the 1956 Hush- $A$-Phone case, ${ }^{161}$ involving a plastic device designed to attach to the phone to reduce the risk of overhearing a phone call, the D.C. Circuit held that prohibition of a "foreign attachment" supplied by the telephone customer was "in unwarranted interference with

154. MCI Telecomms. Corp. v. FCC, 561 F.2d 365 (D.C. Cir. 1977) [hereinafter Execunet I]; MCI Telecomms. Corp. v. FCC, 580 F.2d 590 (D.C. Cir. 1978) [hereinafter Execunet II]; Lincoln Tel. \& Tel. Co. v. FCC, 659 F.2d 1092 (D.C. Cir. 1981) [hereinafter Execunet III].

155. The FCC stated:

Since [the existing carriers] have indicated that they will not voluntarily provide loop service we shall retain jurisdiction of this proceeding in order to enable MCI to obtain from the Commission a prompt determination on the matter of interconnection. Thus, at such time as MCI has customers and the facts and details of the customers' requirements are known, $\mathrm{MCI}$ may come directly to the Commission with a request for an order of interconnection.

Applications of Microwave Commc'ns, Inc., 18 F.C.C.2d 953, 965 (1969).

156. Execunet II, 580 F.2d at 591.

157. Bell Sys. Tariff Offerings, 46 F.C.C.2d 413, 438 (1974), affd sub nom. Bell Tel. Co. of Pa. v. FCC, 503 F.2d 1250.

158. See AT\&T Co., 67 F.C.C.2d 1455 (1978)

159. Execunet II, 580 F.2d at 592 .

160. ZARKIN \&ZARKIN, supra note 146, at 64.

161. Hush-A-Phone Corp. v. United States, 238 F.2d 266 (D.C. Cir. 1956); see also Kearney \& Merrill, supra note 79, at 1341 (noting that with respect to equipment provided by customers, "although the lawfulness of this restriction was called into question as early as 1956 in the Husb-a-Phone case, the FCC did not begin requiring carriers to unbundle customer premises equipment from local phone service until the late 1960s" (footnote omitted)). 
the telephone subscriber's right reasonably to use his telephone in ways which are privately beneficial without being publicly detrimental." ${ }^{162}$

Then, in 1968, the FCC ruled in the Carterfone case ${ }^{163}$ that AT\&T's prohibition of the Carterfone device that manually connected private twoway radio systems to the telephone network was unlawful and that privately manufactured devices could connect to the telephone network as long as their manufacturers met interface standards. ${ }^{164}$ The FCC's ruling in Carterfone had the far-reaching impact of allowing the FCC to deregulate customer premises equipment. ${ }^{165}$ This cleared the way not only for MCl's system to connect to the telephone network but also for devices such as answering machines, fax machines, and modems to connect without network alterations by the telephone company. ${ }^{166}$ As a recent commentary puts it, "[t]he Carterfone decision enabled consumers to purchase modems from countless sources .... Without easy and inexpensive consumer access to modems, the Internet would not have become the global medium that it is today."167

Perhaps even more important in establishing open access principles was the FCC's Computer Inquiries series of three landmark decisions occurring in 1966, 1976, and 1986. ${ }^{168}$ These decisions, while completely different from one another in context and results, addressed two different themes centering on the rapid advancement of computer technologies and their interaction with the telephone network. The new technology (which Computer I called "data processing") was "highly competitive and innovative and demonstrate[d] no need for regulation." ${ }^{69}$ Yet the ability of new service providers to compete with the established telephone companies depended on them to make the

162. Hush-A-Phone Corp., 238 F.2d at $267,269$.

163. In re Carterfone Device in Message Toll Tel. Serv., 13 F.C.C.2d 420 (1968).

164. Id. at $423-24$.

165. The FCC's customer premises equipment rules are found today at 47 C.F.R. pt. 68 (2013).

166. See David Brodwin, Carterfone Case Showed How Regulations Promote Competition, U.S. NEWS \& WORLD REP. (June 28, 2012), http:/www.usnews.com/opinion/blogs/economicintelligence $/ 2012 / 06 / 28 /$ carterfone-case-showed-how-regulations-promote-competition.

167. Jason Oxman, The FCC and the Unregulation of the Internet 15 (Fed. Commc'ns Comm'n Office of Plans \& Policy, Working Paper No. 31,1999), available at http://www.fcc.gov/working-papers/fccand-unregulation-internet.

168. Regulatory \& Policy Problems Presented by the Interdependence of Computer \& Commc'n Servs. \& Facilities, 28 F.C.C.2d 291 (1970) [hereinafter Computer I] (tentative decision); Amendment of Sec. 64.702 of the Comm'n's Rules \& Regulations (Second Computer Inquiry), 77 F.C.C.2d 384 (1980) [hereinafter Computer II] (final decision); Amendment of Secs. 64.702 of the Comm'n's Rules and Regulations. (Third Computer Inquiry), 104 F.C.C.2d 958 (1986) [hereinafter Computer III] (report and order).

169. Robert Cannon, The Legacy of the Federal Communications Commission's Computer Inquiries, 55 FED. COMM. L.J. 167, 180 (2003). 
communications network available. As a former Senior Counsel of the FCC has noted:

Computer services were a disruptive technology. They were substitute services for traditional incumbent communication services. They were highly competitive, highly innovative, and had low barriers to entry. ... In addition, these computer network services were dependent upon the underlying communications network. Thus, the unregulated computer services were simultaneously substitute services for the traditional regulated communications networks and also dependent upon them. ${ }^{170}$

The FCC had to determine whether it had regulatory jurisdiction to address this problem and, if it did, whether to establish safeguards that would allow the new market for data processing services to grow while simultaneously ensuring that regulated telephone companies would not dominate it. ${ }^{171}$ At first, these safeguards were structural. Under Computer I's Maximum Safeguards policy, telephone companies could enter the computer services market but had to establish separate subsidiaries to do so. ${ }^{172}$ Over the course of its next two decisions, the FCC adjusted its remedies. The Comparably Efficient Interconnection provision of Computer III, for example, required the newly formed RBOCs to open their networks to providers of computer services. ${ }^{173}$

Throughout the Computer Inquiries decisions, the FCC went well beyond requiring interconnection of physical equipment to the phone network. It embarked on far-reaching experiments to open the communications network to providers of enhanced services. The importance of this series of decisions cannot be overstated. One scholar terms the Computer Inquiries decisions "a necessary precondition for the success of the Internet."

This lengthy story of encouragement of competition to the established telephone network has many potential lessons for the transformation of the electric grid. First and foremost, it demonstrates that persistence of governmental support and encouragement over a period of decades may be required to overcome the monopoly position of entrenched incumbents. Governmental policy encouraging new technologies came at the highest level, in the form of a Presidential Task Force. ${ }^{175}$ Later, as the history of microwave transmission demonstrates, three

170. Id. at 168 .

171. See id. at 169.

172. Computer I, supra note 168 , at 302-04.

173. Computer III, supra note 168 , at 962-64.

174. Cannon, supra note 169 , at 169.

175. See supra note 121 and accompanying text. 
distinct types of support were necessary: (1) support for the technology itself (the Above 890 decision, for example), ${ }^{176}$ (2) support for specific individual companies (the decision on MCl's application, for example), ${ }^{177}$ and (3) support for entire disruptive industries and service providers (in Specialized Common Carriers and Computer Inquiries, for example). ${ }^{178}$

As was the case with $\mathrm{MCl}$ in telephone service, licensing of specific entrants into competition with utilities might be necessary to transform the electric grid. ${ }^{179}$ Depending on which market competitors would enter, licensing might take action by state PUCs, not FERC. If the competitors were selling electricity to retail customers, they would be subject to state regulation of their entry into the business. This might also require the new entrants to face the same quantum of regulation as incumbent utilities. Proceedings akin to Specialized Common Carriers might be necessary at the state level to determine whether different treatment of new entrants is warranted.

Another prerequisite would be widespread implementation of policies requiring direct interconnection with the electric grid for specific providers of products and services to end use consumers, and years to enable these providers to grow and compete with established utilities (as MCI and its competitors had before open access was established). As an example of this, the battles over expanded net metering may turn out to be the electric grid's Carterfone. ${ }^{180}$ They may someday be remembered not as much for the specific technology connected to the grid (no one in 2014 uses a Carterfone) or the means of connection, but for introducing the principle of universal direct connection to the grid and, therefore, making more comprehensive business models possible.

\section{c. Risks in Relying on the Model}

The risks involved in relying on any one particular combination of timing and regulatory transformation include financial risks (upstart firms' investment is unstable, transaction costs may mount, and competitors may be at a disadvantage against incumbents) and federalism concerns. One central financial risk in the telecommunications model is apparent from the sheer

176. See supra note 118 and accompanying text.

177. See supra notes $119-20,123-24$ and accompanying text.

178. See supra notes $125-28$ and accompanying text.

179. See, e.g., Joel B. Eisen, Can Urban Solar Become a "Disruptive" Tecbnology?: The Case for Solar Utilities, 24 NOTRE DAME J.L. ETHICs \& PUB. POL'Y 53 (2010) (calling for chartering of solar utilities as competitors to utilities).

180. Supra notes $62-66$. 
length of time that elapsed between the Carterfone case and the 1996 Act: It might take decades to establish the principle of full open access in the electricity distribution network. Consequently, the benefits from encouraging competition might be lost or diminished in the near term. If no robust expansion of consumer demand and services follows the near-term regulatory encouragement, the financial advantages to be gained from open access may never materialize.

Another risk is that prospective entrants into competition with utilities may incur the substantial transaction costs of a lengthy confrontation. The personal persistence and tenacity of William McGowan, MCI's founder, was pivotal in leading to open access in long-distance telephone service. ${ }^{181} \mathrm{It}$ might take a similar individual or group to do the same in the electric grid. And $\mathrm{MCI}$ pursued its cause in multiple fora: before the FCC, in the federal courts, and elsewhere. ${ }^{182}$ This was an expensive proposition. A recurring joke at the time was that MCI was a "law firm with an antenna on the roof"183 because it spent large sums on litigation fighting AT\&T. Many utilities are Fortune 500 companies with deep pockets. ${ }^{184}$ Their competitors, like MCI, should similarly be prepared to expend substantial resources.

If the history of telephone regulation is an indication, potential entrants must also be prepared to deal with delays that can stretch into years. As noted above, the FCC took several years to approve MCI's original application before the FCC. ${ }^{185}$ Even after the Carterfone decision, it took several years for the FCC to issue rules on connection of customer provided equipment. ${ }^{186}$ The electric grid is no stranger to delay (consider the length of time it has taken some states to put in place and expand their net metering programs ${ }^{187}$ ), so a long-term commitment to disrupting the electric distribution network will be

181. See, e.g., Carla Lazzareschi, MCI Founder McGorvan Is Dead at 64, L.A. TIMES, June 9, 1992, http://articles.latimes.com/1992-06-09/business/fi-282_1_bill-mcgowan ("McGowan almost single-handedly popped the telephone monopoly .... He got past the regulators, the industry, the 182. Id. lobbyists and the courts." (internal quotation marks omitted)).

183. Id.

184. Twenty-two gas and electric utilities, including such heavyweights as Exelon (\#145), Southern (\#152), Duke Energy (\#186), and Dominion Resources (\#187) are members of the Fortune 500. See Fortune 500, CNN MONEY (May 21, 2012), http://money.cnn.com/magazines/fortune/fortune500/2012/ industries/143.

185. See supra notes $119,123-24$ and accompanying text

186. The FCC first issued rules on CPE in 1980, over a decade after Carterfone. Fed. Commc'ns Comm'n, Connection of Telephone Equipment, Systems and Protective Apparatus to Certain Private Line Services, and Related Changes; Signal Power Limitations; Accommodation of 4-Wire Telephone Network Connections and Interfaces, 45 Fed. Reg. 20,830 (Mar. 31, 1980).

187. Net Metering, supra note 59. 
required of any would-be competitors. Reversals of hard-won victories (such as the FCC's original decision not to require interconnection of MCI's Execunet service ${ }^{188}$ that prompted the series of lawsuits described above) will take place, and will require still more in the way of commitment.

The power dynamics of the 1996 Act's grand bargain suggest yet another risk. Competitors may have to accrue political power so legislators and regulators view them as viable alternatives to incumbent utilities and as equally deserving participants in their own right in agency and legislative deliberations. The grand bargain took place between two sets of entities (AT\&T and the RBOCs) that were major companies, not start-ups. By contrast, competitors in the electric grid today do not have the same ability to wield political clout as utilities that have lengthy records of interaction with FERC and state PUCs.

Finally, there are numerous federalism risks. An important one is that as new entrants find their way into competition, there may be debates about which level of government has jurisdiction to handle disagreements. As an example in telephone regulation, in 1973, AT\&T resisted the FCC's request that it offer interconnection to MCl's facilities and stated that it would take this issue up with the state PUCs that regulated it. ${ }^{189}$ The FCC responded that it, not state commissions, had jurisdiction, and the matter was ultimately settled by the Third Circuit. ${ }^{190}$ With the smart electricity network, this risk is greater because the line in electricity regulation between federal and state government jurisdiction is not precise. ${ }^{191}$ Already, there are high-profile battles over the limits of state and federal authority to reshape the electric grid, and, as the telephone model suggests, they are almost certain to continue. This does not mean that open access is impossible to achieve, but it does suggest that more uncertainty and delay are possible.

\section{d. Final Thoughts About the Telephone Model}

The timing of policy evolution one would expect in a smart electricity network following the telephone regulation model might be best described as early-stage encouragement of disruptive technologies, followed by intervention to define network access and rules at a tipping point. It would require near-term

188. See AT\&T Co., 67 F.C.C.2d 1455 (1978).

189. Bell Tel. Co. of Pa. v. FCC, 503 F.2d 1250, 1256 (3d Cir. 1974) ("AT\&T informed the Commission that it would provide local loop service to MCI, but that it could do so only after first receiving clearance from the appropriate state regulatory commissions.").

190. Id. at 1257,1282

191. See infra notes $208-216$ and accompanying text. 
regulatory decisions and would culminate in congressional intervention through amendments to the Federal Power Act (FPA), not a regulatory OADT.

That distinction hardly means the telecommunications model is inapt. Despite the occasional dissimilarities, many of its parallels resonate deeply in the challenges inherent in building out a national network. The model depends on a consensus that new business opportunities depend on open access, which can develop at any time as the preferences of participants in the process shift. This suggests that there is a long course ahead for open access to the electric grid, with many intermediate steps necessary before full open access is in place. If indicators of a market share shift are significant enough to warrant intervention - for example, the fear on the part of utilities that they will lose market share materializes more concretely into actual market losses-then it may be time to move forward and propose a principle of open access. Conversely, if we have gone too long without significant take-up of new technologies, we may need to do more lest the market share shift never occur.

\section{B. The Electricity Model}

Another possible model for the transformation to a smart electricity network is the earlier overhaul of the electricity industry itself. During the restructuring that began in the $1990 \mathrm{~s},{ }^{192}$ FERC issued a series of landmark rules designed to create wholesale markets for electricity and open the nation's transmission lines.

\section{Regulatory Evolution and Appeal of the Electricity Model}

The restructuring of the electric grid was prompted in part by two major FERC rules. FERC Order 888, discussed in more detail above, promoted wholesale competition through open access to transmission services by public utilities. ${ }^{193}$ FERC Order 2000 encouraged the formation of "Regional Transmission Organizations" (RTOs) to supervise regional grids and promote the development of new transmission capacity. ${ }^{194}$

One appealing aspect of this parallel is that it took place in the electric grid. Restructuring was at least partially successful in reforming and providing open access to the electric grid and opening the nation to electricity competition. ${ }^{195}$

192. See, e.g., Richard J. Pierce, Jr., Completing the Process of Restructuring the Electricity Market, 40 WAKE FOREST L. REV. 451 (2005).

193. FERC Order 888, supra note 3.

194. Regional Transmission Organizations, 65 Fed. Reg. 810 (Jan. 6, 2000) [hereinafter FERC Order 2000] (to be codified at 18 C.F.R. pt. 35).

195. See, e.g., id. 
In restructuring, monopolies in interstate transmission of electricity ended, and much of the nation saw competition at the retail level with consumers able to choose their electricity generators. ${ }^{196}$ In sixteen states, customers can choose the entity that generates their electricity, although in all but Texas, the customer still receives electricity from the incumbent distribution utility. ${ }^{197}$ In the end, traditional vertically integrated utilities still serve millions of consumers. ${ }^{198}$ Even so, the opening of transmission lines and promoting wholesale competitionand the resulting partial deregulation of the industry at the retail level-make the electricity model useful to consider.

\section{Lessons for a Smart Electricity Network}

\section{a. Signifiers That a Transition to Open Access Is Possible}

In Order 888, FERC set forth a different and expanded interpretation of its statutory mandate, responding to the shifting conditions in the industry. Order 888 begins with a lengthy discussion of changing conditions in the electricity industry and follows with a conclusion that transmission owners were hindering a more dramatic transformation of the industry:

However, it became increasingly clear that the potential consumer benefits that could be derived from these technological advances could be realized only if more efficient generating plants could obtain access to the regional transmission grids. Because many traditional vertically integrated utilities still did not provide open access to third parties and still favored their own generation if and when they provided transmission access to third parties, barriers continued to exist to cheaper, more efficient generation sources. ${ }^{199}$

In issuing Order 888, FERC broadened its traditional interpretation of its undue discrimination authority under the FPA. ${ }^{200}$ Traditionally, an undue discrimination inquiry focused on similarly situated third-party customers; if

196. Status of Electricity Restructuring By State, U.S. ENERGY INFO. ADMIN., http://www.eia.gov/elec tricity/policies/restructuring/restructure elect.html (last visited July 5, 2014) (mapping states in which retail competition is active as of 2010).

197. MASS. INST. OF TECH, supra note 15.

198. 2012 Utility Bundled Retail Sales-Residential, U.S. ENERGY INFO. ADMIN., http://www.eia.gov/ electricity/sales_revenue_price/pdf/table6.pdf (last visited July 5, 2014).

199. FERC Order 888, supra note 3 , at $21,546$.

200. Section 205 of the Federal Power Act prohibits unreasonable rates and undue discrimination "with respect to any transmission or sale subject to the jurisdiction of the Commission," 16 U.S.C. $\$ 824 \mathrm{~d}(\mathrm{~b})(2012)$, and Section 206 gives FERC the power to correct such unlawful practices, 16 U.S.C. $\$ 824(\mathrm{e})$ (2012). 
they faced different rates, terms, or conditions, the inquiry became whether factual differences among these customers justified disparate treatment. ${ }^{201}$ In Order 888, FERC extended this inquiry to consider the rates, terms, and conditions of customers using transmission lines as compared to a utility's use of its own transmission system. ${ }^{202}$

FERC based its Order on judicial comparability decisions finding that conditions had changed in the electric utility industry. ${ }^{203}$ In Order 888 , FERC decided that an OATT was necessary to address undue discrimination precisely because it would require a transmission provider to offer all those seeking transmission service the same terms and conditions as the transmission owner's own use. ${ }^{204}$ While this was an extension of its prior exercises of power, it justified its position given the changing industry landscape, including the greater availability of generators that wished to use the transmission lines but had found it difficult to secure access, as noted above. ${ }^{205}$

Similarly, a finding that the current grid structure hampers the desired open access would support FERC action to promulgate an OADT. One could imagine the sort of anticompetitiveness findings that would be necessary to support an OADT. In a smart electricity network, for example, consumers with smart meters could contract with aggregators (firms that bundle together demand reductions from a number of consumers and offer the resulting demand response resources into wholesale markets) to monetize their demand reductions, but these firms face regulatory hurdles that hamper their growth. ${ }^{206}$ At some point, FERC would make a foundational finding that it was time to remove the obstacles to more widespread use of this or any other resource by consumers on the distribution lines.

If FERC were to proceed in this fashion, it would have to find that utilities have engaged in undue discrimination against those nonincumbents seeking to use the distribution lines to buy or sell electricity (consumers, for example). But this may not be as difficult a burden as one might imagine. FERC is not required to compile particularized factual findings and can re-

201. Clark Evans Downs \& Kenneth B. Driver, Can The FERCL Lawfully Order Transmission Providers To Participate In An ISO? Will It Anyway? 12 (1998), available at http://www.hks.harvard.edu/hepg/ Papers/Old_Papers/Downs_FERCLawful1998.pdf(discussing this with reference to Order 888).

202. Id. at $12-13$.

203. FERC Order No. 888, supra note 3, at 21,547-48 (discussing the American Electric Power case involving undue discrimination).

204. FERC Order 888, supra note 3, at 21,593.

205. FERC Order 888 , supra note 3.

206. Eisen, supra note 140 , at 84. 
ly on an industry-wide assessment of behavior that amounts to undue discrimination. ${ }^{207}$

\section{b. Necessary Regulatory Prerequisites}

Like regulatory evolution in telephone service, FERC's actions to provide open access to the interstate transmission of electricity took place after more than a decade of experience with public policies designed to change the electric grid. Order 888 and Order 2000 followed federal statutes (notably the Public Utility Regulatory Policies Act of 1978 (PURPA) ${ }^{208}$ and the Energy Policy Act of $1992^{209}$ ) that encouraged alternatives to traditional incumbent utilities. These laws led to the creation of a class of would-be competitors to utilities (wholesale generators). But these wholesale generators still lacked one essential element of success: the ability to move their electricity on the grid, which was stymied by the monopoly power of transmission owners. ${ }^{210}$

Policies currently gaining traction in the states-net metering and demand response, ${ }^{211}$ for example - have had similarly significant effects in prompting the rise of alternatives to traditional utilities, despite the utilities' ongoing opposition. ${ }^{212}$ Yet none of them do enough to reverse the historical biases in the system. Existing legal and regulatory systems tilt strongly in favor of incumbent utilities and pose significant hurdles for companies such as

207. An example of this is the discussion of FERC's findings to support Order 888 in the D.C. Circuit opinion upholding that Order. Transmission Access Poly Study Grp. v. FERC, 225 F.3d 667, 687 (D.C. Cir. 2000), affd on other grounds sub nom; New York v. FERC, 535 U.S. 1 (2002) (supporting FERC's reliance on generic findings of undue discrimination over opponents' objections that "substantial evidence of contemporaneous 'unjust, unreasonable, unduly discriminatory or preferential' behavior" was required). One critic of recent FERC initiatives acknowledges FERC's ability to make industry-wide findings of undue discrimination, but criticizes its use in specific contexts. Matthew R. McGuire, (Mis) understanding "Undue Discrimination": FERC's Misguided Effort to Extend the Boundaries of the Federal Porwer Act, 19 GEO. MASON L. REV. 549 (2012).

208. Public Utility Regulatory Policies Act of 1978, Pub. L. No. 95-617, 92 Stat. 3117 (1978).

209. Energy Policy Act of 1992, Pub. L. No. 102-486, 106 Stat. 2776 (1992).

210. FERC Order 888, supra note 3, at 21,568.

211. U.S. DEPT. OF ENERGY, BENEFITS OF DEMAND RESPONSE IN ELECTRICITY MARKETS AND RECOMMENDATIONS FOR ACHIEVING THEM, at v (2006), available at http://energy.gov/sites/ prod/files/oeprod/DocumentsandMedia/DOE_Benefits_of_Demand_Response_in_Electricity_M arkets_and_Recommendations_for_Achieving_Them_Report_to_Congress.pdf ("Demand response is a tariff or program established to motivate changes in electric use by end-use customers in response to changes in the price of electricity over time, or to give incentive payments designed to induce lower electricity use at times of high market prices or when grid reliability is jeopardized.").

212. Supra notes $62-66$. 
solar services firms that might seek to be network participants. ${ }^{213}$ The firms also face diseconomies of scale and high coordination problems, prompting commentators to argue that the federal government needs to take dramatic action to support renewables industries. ${ }^{214}$ It already has, with FERC's Order 1000 prompting a planning process to build transmission lines to transport electricity generated from wind or solar from its source to a customer base. ${ }^{215}$ Yet even if renewables firms were able to gain market share, the regulatory actions taken to date are largely meant to prompt the development and deployment of technology, not to set network rules for open access at the distribution level.

FERC's landmark Order 1000, which establishes regional and interregional planning for new transmission lines, provides for the development of new methodologies to allocate the costs of new transmission lines and promotes development of transmission lines by parties other than incumbent transmission line owners. ${ }^{216}$ Order 1000's dry language masks the fundamental change this rule may bring in overhauling the generation mix on the electric grid by linking electricity generated from renewable resources to the existing grid. ${ }^{217}$

Similarly, FERC Order $745^{218}$ calls for participants to bid aggregated amounts of demand response into wholesale markets and receive the same prevailing price as generators receive for their electricity. In the aggregate, it also can serve as a resource that grid operators can use to meet demand, rather than calling on existing power plants. ${ }^{219}$ Recognizing this, Order 745 requires compensation of a demand response bid as a resource into wholesale markets at the full locational marginal price. Order 745 's ultimate fate is in doubt af-

213. See Eisen, supra note 71 (discussing distribution-level barriers to more widespread deployment of renewable energy).

214. Eisen, supra note 179 (arguing for "solar utilities").

215. See generally Alexandra B. Klass \& Elizabeth J. Wilson, Interstate Transmission Challenges for Renewable Energy: A Federalism Mismatch, 65 VAND. L. REV. 1801 (2012).

216. Transmission Planning and Cost Allocation by Transmission Owning and Operating Public Utilities, 76 Fed. Reg. 49842, 49880 (Aug. 11, 2011) [hereinafter FERC Order 1000] (to be codified at 18 C.F.R. pt. 35); see Klass \&Wilson, supra note 215.

217. See, e.g., Adam James \& Whitney Allen, FERC Order 1000: The Most Exciting Energy Regulation You've Never Heard of, CLIMATE PROGRESS (Oct. 22, 2012, 11:30 AM), http://thinkprogress.org/ climate/2012/10/22/1059091/ferc-order-1000-the-most-exciting-energy-regulation-youvenever-heard-of.

218. Demand Response Compensation in Organized Wholesale Energy Markets, 76 Fed. Reg. 16658 (Mar. 24, 2011) (to be codified at 18 C.F.R. pt. 35).

219. Eisen, supra note 140, at 77-78. 
ter a D.C. Circuit panel decision invalidating it, ${ }^{220}$ although a request for rehearing is pending. But if it is eventually upheld, some observers believe that Order 745 may spur dramatic growth in demand response deployment and set an important precedent to include resources beyond traditional generating capacity on the Smart Grid, including benefits such as greenhouse gas emissions reductions. ${ }^{221}$

\section{c. Risks in Relying on the Model}

The principal risk that FERC would encounter in promulgating an OADT based on open access transmission principles is that it lacks statutory authority over retail sales of electricity. Under Section 201 of the FPA, FERC's authority extends to "the transmission of electric energy in interstate commerce and the sale of such energy at wholesale in interstate commerce." 222 In the restructuring Orders, FERC was acting to create wholesale markets and open the transmission lines, not to regulate the retail distribution of electricity, which has been the states' responsibility. This jurisdictional dividing line is anything but clear ${ }^{223}$ and has been the subject of tension for well over two decades. Indeed, concerns about FERC authority suggest that promulgating an OADT might push FERC's jurisdiction beyond its current limits.

FERC's recent assertions of regulatory authority over the electric grid are already being challenged in high-profile lawsuits attacking Orders 745 and 1000 . Decisions in these cases will go a long way toward determining whether FERC would face jurisdictional risk if it were to promulgate an OADT. The first lawsuit is a consolidated challenge to Order 1000, which to many involves a "significant shift in FERC's view of its jurisdiction." ${ }^{24}$ In the

220. Elec. Power Supply Ass'n v. FERC, No. 11-1486 (D.C. Cir. May 23, 2014); Joel B. Eisen, D.C. Circuit Vacates FERC Smart Grid "Demand Response" Rule, CPR Blog, Legal Planet (May 30, 2014), http://legal-planet.org/2014/05/30/guest-blogger-joel-eisen-d-c-circuit-vacatesferc-smart-grid-demand-response-rule/.

221. Eisen, supra note 140, at 71; Rasika Athawale, Demand Response in the US Electricity Market, THE ENERGY COLLECTIVE (Mar. 7, 2013), http://theenergycollective.com/rasika-athawale/195536/ demand-response-us-electricity-market.

222. 16 U.S.C. $\$ 824(2012)$.

223. Linda L. Walsh \& Noelle J. Coates, Walking the Fuzzy Bright Line, PUB. UTIL. ForT. 40, 43 (Sept. 2013), http:/www.hunton.com/files/Publication/27eb7751-6e4e-4822-bdc4 -0dd7532ce57e/Presentation/PublicationAttachment/a76c02b2-4f91-4801-b3f4d073c 97d64ee/Walking_the_Fuzzy_Bright_Line.pdf ("In matters of transmission, that [jurisdiction boundary] line's location has always been a bit fuzzy.").

224. McGuire, supra note 207. 
lawsuit pending in the D.C. Circuit, ${ }^{225}$ FERC's opponents raise a number of jurisdictional objections. For example, one centers on Order 1000's removal of the right of first refusal (ROFR) for transmission projects identified in a regional plan for the purposes of cost allocation. ${ }^{226}$ As a result of Order 1000, incumbent utilities will no longer have the right of first refusal to build, own, and operate large-scale transmission projects located within their service territory. In the past, transmission projects have traditionally been assigned based upon geographic location and service territory. ${ }^{227}$ Without an ROFR, these may now be open to competition. FERC's stated basis for removal of the ROFR is that it is attempting to encourage nontraditional investment by removing obstacles to nonincumbent developers of transmission lines. In other words, FERC used the undue discrimination standard of FPA Section 206 to conclude that the ROFR has stymied the ability of new entrants in the transmission business. ${ }^{228}$

One commentator argues that this is a significant expansion of FERC's undue discrimination authority because " $[t]$ he problem of independent companies seeking to invest in and construct transmission lines in the footprint of traditional electric utilities was not envisioned at the time the tariffs were filed with FERC." 229 Others point to a direct conflict with state regulatory authority in that "[s]tates have traditionally assumed all jurisdiction to approve or deny permits for the siting and construction of electric transmission facilities." ${ }^{230}$ While the fate of the Order 1000 lawsuit is unclear, the Supreme Court has already upheld FERC's authority to promote a class of competitors to incumbents, even if it threatens to interfere with matters traditionally re-

225. South Carolina Public Service Authority v. FERC No. 12-1232 (D.C. Cir. flled May 25, 2012); Alice Clamp, The Trouble With Order 1000, Pub. Power (June 6, 2013), http://publicpower.org/Media/ magazine/ArticleDetail.cfm? ItemNumber $=38067$ (describing the litigation).

226. FERC Order 1000 , supra note 216 , at 49,880 .

227. Greg Stark, Why FERC Order 1000 is a Big Deal in the Electric Industry, ENERDYNAMICS (Nov. 30, 2012), http://blog.enerdynamics.com/2012/11/30/why-ferc-order-1000-is-a-big-deal-inthe-electric-industry.

228. FERC Order 1000, supra note 216, at 49,880 ("We conclude these reforms are necessary in order to eliminate practices that have the potential to undermine the identification and evaluation of more efficient or cost-effective alternatives to regional transmission needs, which in turn can result in rates for Commission-jurisdictional services that are unjust and unreasonable, or otherwise result in undue discrimination by public utility transmission providers."); see also Statement of Chairman Jon Wellinghoff on Right of First Refusal (ROFR) Orders, FED. ENERGY REGULATORY COMM'N (July 19, 2012), http://www.ferc.gov/ EventCalendar/Files/ 20120719164044-E-11-WELLINGHOFF.pdf.

229. McGuire, supra note 207 , at 589 .

230. Walsh \& Coates, supra note 223, at 43. 
served to the states. In New York v. FERC, ${ }^{231}$ the Court upheld the restructuring Orders as a valid exercise of FERC's FPA authority to address anticompetitive, discriminatory behavior on an industry-wide basis if it relates to transmission service on the interconnected electric grid. ${ }^{232}$

New York v. FERC also makes it clear that even if FERC policies have impacts at the retail level, if the transmission grid is affected, it may regulate activity that involves interstate transmission. As the Court stated in New York, " $[\mathrm{N}]_{\mathrm{o}}$ statutory language limits FERC's transmission jurisdiction to the wholesale market, although the statute does limit FERC's sales jurisdiction to that market." 233 This suggests that FERC's authority over transmission at all levels of the existing interconnected transmission grid may justify an OADT. Using this logic, FERC would assert that an OADT is remedying discrimination that has the effect of precluding providers of products and services from access to the transmission network. But it would have to overcome the language in New York that limits FERC's authority to interstate transmission and not to retail sales. This, as noted above, might require amendments to the FPA.

A second ongoing test of FERC's authority is EPSA v. FERC, ${ }^{234}$ the challenge to Order 745. Order 745's concept of compensating negawatts (reductions in consumption) on a level playing field with megawatts generated has been controversial. ${ }^{235}$ In $E P S A v$. FERC, a broad coalition of states and industry associations claimed in part that FERC overstepped its authority as the wholesale markets' regulator, controlling a matter subject to exclusive states' jurisdiction. ${ }^{236}$ FERC justified Order 745 under FPA Section 205's grant of authority to it over matters "affecting or pertaining to" wholesale prices. ${ }^{237}$ FERC therefore claimed it has authority to regulate DR in part because

231. 535 U.S. 1 (2002).

232. Eisen, supra note 140 , at $94-95$.

233. New York v. FERC, 535 U.S. 1 (2002).

234. No. 11-1486 (D.C. Cir. filed June 6, 2012).

235. Richard J. Pierce, Jr., A Primer on Demand Response and a Critique of FERC Order 745, $3 \mathrm{~J}$. ENERGY \&ENVTL. L. 102 (2012).

236. Elec. Power Supply Ass'n v. FERC, No. 11-1486 (D.C. Cir. May 23, 2014); see also Bobby McMahon, Federal Judges Hear Arguments on US FERC Demand Response Order, PLATTS MCGRAW HILL FinANCIAL (Sept. 23, 2013, 4:12 PM), http://www.platts.com/latestnews/electric-power/washington/federal-judges-hear-arguments-on-us-ferc-demand-21595334 (noting the clash over jurisdiction at oral argument of EPSA v. FERC); Bruce W. Radford \&Michael T. Burr, Federal Feud: The Jurisdictional Battle Rages on, With FERC and EPA Squaring Off Against the States, PUB.UTIL. ForT., Nov. 2012, at 30, 31 ("In this case, we force the court to decide just what is the boundary between federal and state jurisdiction, ... . Most cases tend to nibble around it, but with this one the issue is front and center." (quoting John Shelk, EPSA's president and CEO)).

237. 16 U.S.C. $\$ 824 \mathrm{~d}($ a) (2012); Eisen, supra note 140 , at 72. 
of its significant and wide-ranging impacts on wholesale markets (for example, by tamping demand at peak hours and decreasing the need for grid operators to call up reserve generation capacity). ${ }^{238}$

In May 2014, a panel of the D.C. Circuit split 2-1 rejected this assertion of jurisdiction, vacating Order 745 and terming demand response a retail-level product subject to exclusive state authority. ${ }^{239}$ If this decision stands, it will be difficult for FERC to set rules for many products and services that could be viewed as retail-level and subject to state regulation. ${ }^{240}$ For that reason, FERC would have no authority to take the broader action of promulgating an OADT, unless Congress amended the FPA to give it that power. At this moment, it appears likely that FERC will seek rehearing en banc at the D.C. Circuit. If Order 745 is eventually upheld, and FERC can regulate DR bid into wholesale electricity markets, then it will have the beginnings of a foundation to interpret existing statutory authority to establish an OADT.

The expected physical or economic linkage of smart electricity network infrastructure and applications nationwide may give FERC more justification to act. On a network where multimodal, multidirectional transactions are contemplated, the division of regulatory authority may not be reducible to simply articulating retail versus wholesale jurisdictional boundaries between the federal and state governments and walling off separate spheres of regulatory influence. FERC could extend its interpretation of section 205 to the OADT, contending that consumers offering electricity for sale across the nation significantly affect the wholesale markets. Using the logic of City of Arlington v. FCC, ${ }^{241}$ FERC could be entitled to Chevron ${ }^{242}$ deference for a finding that its authority to regulate matters affecting the wholesale markets extends to the development of an OADT. In the near term, however, unless the panel

238. Elec. Power Supply Ass'n v. FERC, No. 11-1486, at 7. As has been observed in another context, FERC's authority gives it considerable discretion "to consider some matters going beyond the direct financial interests of buyers and sellers in wholesale transactions [such as] 'conservation, environmental, and antitrust questions." Michael H. Dworkin \& Rachel Aslin Goldwasser, Ensuring Consideration of the Public Interest in the Governance and Accountability of Regional Transmission Organizations, 28 ENERGY L.J. 543, 545 (2007) (quoting NAACP v. Fed. Power Comm'n, 425 U.S. 662 (1976)).

239. Elec. Power Supply Ass'n v. FERC, No. 11-1486.

240. Eisen, supra note 220.

241. City of Arlington v. FCC, 133 S. Ct. 1863 (2013) (using Chevron to uphold the FCC's interpretation of its jurisdiction, and rejecting a challenge to that construction on the basis that it intruded impermissibly into matters of exclusive state jurisdiction).

242. Chevron U.S.A., Inc. v. Natural Resources Defense Council, Inc., 467 U.S. 837 (1984) (providing a two-step test for a court to use in deciding whether to defer to an agency's construction of a statute it administers). Of course, Chevron has been the subject of an extensive body of literature, and the actual application to this hypothetical context is beyond the scope of this Article. 
decision in Electric Power Supply Association is overturned, the jurisdictional uncertainty is the most significant risk highlighted by the electricity restructuring model. ${ }^{243}$

Still another risk that FERC faces is that unlike the breakup of the Bell System in telecommunications, restructuring has not left the electric utility industry with a predisposition to deregulate. Exactly the opposite is true in parts of the nation where restructuring never took hold, with many states returning to principles of traditional regulation. To avoid disruptive jurisdictional clashes in the near term, the history of restructuring suggests that moving the concept of expanded distribution access forward may be best achieved through a joint effort instead of an outright assertion of authority. This would entail FERC involving state regulators in the national conversation to decide how best to advance an OADT.

\section{The Finance System Model (Dodd-Frank)}

The third and final model involves the comprehensive regulation overhaul of the nation's financial system embodied in the Dodd-Frank Wall Street Reform and Consumer Protection Act (Dodd-Frank). ${ }^{244}$ The financial crisis of the Great Recession, at the heart of which was a banking meltdown in 2008-2009, led to widespread changes in the nation's financial regulatory infrastructure.

This Part will discuss a high-profile Dodd-Frank reform measure: the creation of the Bureau of Consumer Financial Protection(CFPB) ${ }^{245}$ to safeguard

243. The battle over "net neutrality" on the Internet, another area where national network law and policy is rapidly evolving, presents a cautionary tale to FERC about extending its interpretation of its jurisdiction to promote open access. Tim Wu, Network Neutrality, Broadband Discrimination, 2 J. TELECOMM. \&HIGH TECH. L. 141 (2003) (introducing the concept of "net neutrality"). Professor $\mathrm{Wu}$ argued for the Internet to be neutral; that is, to provide open access to all applications and avoid promoting any one application over others. In early 2014 , the D.C. Circuit decided that FCC does not have authority under section 706 of the Telecommunications Act of 1996 to require net neutrality. Verizon v. FCC, Nos. 11-1355, 11-1356, 2014 WL 113946 (D.C. Cir. Jan. 14, 2014). It should be noted that section 706 confers less specific authority on the FCC to regulate market transactions than the FPA does on FERC, so the net neutrality decision is unlikely to have impact in proceedings involving open access on the electric grid.

244. Dodd-Frank Wall Street Reform and Consumer Protection Act (Dodd-Frank), Pub. L. No. 111-203, 124 Stat. 1376 (2010).

245. Title X of Dodd-Frank establishes the Bureau of Consumer Financial Protection (CFPB) as an independent agency within the Board of Governors of the Federal Reserve System. 12 U.S.C. $\$ 5491$ (2012) (defining the Bureau and listing its duties); 12 U.S.C. $\$ 5581$ (b) (2012) (transferring certain consumer protection responsibilities to the CFPB); 12 U.S.C. $\S 5581(\mathrm{a})(1)$ (2012) (defining "consumer financial protection functions" to mean "all authority to prescribe rules or issue orders or guidelines pursuant to any Federal consumer financial law, including performing appropriate functions to promulgate and review such rules, orders, and guidelines"). 
consumers against abuses by financial services firms. As some commentators have noted, the CFPB is arguably the most important federal administrative agency created from scratch in recent memory. ${ }^{246}$ Its creation involved a debate over fundamental questions of how to design an agency's jurisdiction to accomplish a specific set of purposes. Many commentators have written about this development, ${ }^{247}$ and the analysis here can only scratch the surface of the immense and ongoing public policy debate involving the CFPB.

\section{The Appeal of the Financial System Model}

Dodd-Frank seeks to prevent another major financial crisis by creating new regulatory processes that enforce transparency and accountability while implementing rules for consumer protection. ${ }^{248}$ There are some intriguing similarities that make this regulatory overhaul worthy of further consideration. Like the electricity and telecommunications networks, the financial system and the regulatory structure that governs it are a massive interconnected web that is essential to national welfare. Two principal animating concerns for financial system reform-minimizing the probability of financial sector distress by making it possible to liquidate banks deemed "too big to fail," ${ }^{49}$ and guarding against systemic mortgage difficulties through CFPB-are comparable to the need to maintain the electric grid's reliability and security during any transformation to a smart network. Dodd-Frank's series of policy choices holds has important lessons for regulation of the electric grid.

246. Kent Barnett, Codifying Chevmore, N.Y.U. L. REV. (forthcoming 2014) (noting that in creating the CFPB, "Congress reorganized much of the administrative state as it related to consumer financial protection"); Rachel E. Barkow, Insulating Agencies: Avoiding Capture Through Institutional Design, 89 TEX. L. REV. 15, 18 (2010) (terming the CFPB "the most important federal agency created in decades").

247. See, e.g., id.; Jared Elosta, Dynamic Federalism and Consumer Financial Protection: How the Dodd-Frank Act Changes the Preemption Debate, 89 N.C. L. REV. 1273 (2011). For discussions of broader administrative law themes involved in the CFPB's creation, see Barnett, supra note 246; Emily Hammond Meazell, Presidential Control, Expertise, and the Deference Dilemma, 61 DUKE L.J. 1763, 1792-93 (2012) [hereinafter Hammond Meazell].

248. Jeff Merkley \& Carl Levin, The Dodd-Frank Act Restrictions on Proprietary Trading and Conflicts of Interest: New Tools to Address Evolving Threats, 48 HARV. J. ON LEGIS. 515, 515 (2011) ("Congress responded to this financial crisis by enacting the broadest financial reforms since the 1930s. These reforms, which constitute the Dodd-Frank Wall Street Reform and Consumer Protection Act ... seek to protect: (1) the U.S. economy from suffering another debilitating financial crisis; and (2) taxpayers from again being called upon to rescue failed financial firms.")

249. See, e.g., Jeffrey N. Gordon and Christopher Muller, Confronting Financial Crisis: Dodd-Frank's Dangers and the Case for a Systemic Emergency Insurance Fund, 28 YALEJ. ON REG. 151 (2011). 
Financial regulation before Dodd-Frank featured a lack of clarity about jurisdiction of various federal agencies to address consumer protection. ${ }^{250}$ There was a widespread perception that the accretion of new laws and regulations over time in response to major adverse events (in this case, systemic financial crises) was a major contributor to a regulatory structure with numerous gaps and inconsistencies. ${ }^{251}$ Indeed, observers cited these gaps in regulation as a major shortcoming of the system before Dodd-Frank, one that in some cases exacerbated the financial problems of the Great Recession. ${ }^{252}$ The new complex regulatory structure of Dodd-Frank, including the creation of the CFPB, aims to address some of these gaps.

The CFPB aims to protect consumer interests while simultaneously retaining the ability of financial services firms to offer new products and services. ${ }^{253}$ This has resonance in FERC's potential to use its authority in the electric grid to accomplish similar objectives. The specific substantive decisions about this balance are obviously different from those encountered in the electric grid. But when one contemplates extending authority to a federal agency to protect consumers while encouraging new industry entrants, it resembles inquiries that will be encountered in the development of a smart electricity network. Thus, the central questions about allocating power to the CFPB to strike the balance between industry and consumers have some resonance to regulation of the electric grid.

Another important issue raised by the CFPB's creation has an even more obvious parallel to the electric grid: the resolution of the overlapping authority that existed before Dodd-Frank between state and federal governments with respect to protecting financial services firms' consumers. As noted above, the discussion of creating a new consumer financial protection agency frequently addressed this issue, ${ }^{254}$ and that discussion may have important les-

250. WEBEL ET AL., supra note 233, at 10 (terming the pre- Dodd-Frank system of consumer protection "fragmented").

251. Id. at 10. "Currently, the United States has many regulators, some with overlapping jurisdictions, but with gaps in oversight of some issues. This structure evolved largely in reaction to past financial crises, with new agencies and rules created to address the perceived causes of the particular financial problems at that time." Id. at Summary.

252. Id. at 4 (" $[\mathrm{S}]$ ome analysts argue that systemic risk can fester in the gaps in the regulatory system where one regulator's jurisdiction ends and another's begins.").

253. U.S. DEPT. OF TREASURY, FINANCIAL REGULATORY REFORM, A NEW FOUNDATION: REBUILDING FINANCIAL SUPERVISION AND REGULATION 57-58 (2009) (calling for the consumer protection agency to ensure that "consumers are protected from abuse, unfairness, deception, or discrimination" and that "consumer financial services markets operate fairly and efficiently with ample room for sustainable growth and innovation").

254. See supra notes $243-245$ and accompanying text. 
sons for the current difficulties in drawing the state-federal jurisdictional line in electricity regulation.

Still another parallel between the two systems is a somewhat unfortunate one: sweeping financial regulatory change is often crisis-driven. The financial industry is susceptible to a historical recurrence of systemic crises, such as the near-collapse of the banking system in the Great Depression. ${ }^{255}$ And crisis has prompted action: the Glass-Steagall Act, Securities Act of 1933, the Securities Exchange Act of 1934 in the Great Depression era, ${ }^{256}$ as well as the DoddFrank Act today. Similarly, recurring crises have historically been a driver of major change in the electric utility industry, with new laws and policies following the blackouts of 1965, 1977 and 2003 ${ }^{257}$ (for example, reliability standards authority added to the FPA after the 2003 blackout). ${ }^{258}$ Therefore, the lessons learned from how financial regulation evolves in response to crises may have some resonance for the electric grid.

\section{Regulatory Evolution Leading to the Creation of the CFPB}

With the caveat that there are significant differences between financial system regulatory reform and the electric grid, this Part discusses the creation of the CFPB, which is "charged with the Herculean task of regulating the $\mathrm{fi}^{-}$ nancial services industry to protect consumers." ${ }^{259}$ Specifically, it must ensure "that markets for consumer financial products and services are fair, transparent, and competitive." ${ }^{260}$ In 2007, then-Harvard Law School professor Elizabeth Warren first proposed an agency of this type, ${ }^{261}$ and the cataclysmic financial distress of the Great Recession led to a widespread political call to establish a consumer protection agency. ${ }^{262}$ One primary motivation for this was the percep-

255. Markus K. Brunnermeier \& Martin Oehmke, Bubbles, Financial Crises, and Systemic Risk 8 (Nat' Bureau Econ. Research, Working Paper No. 18398, 2012), available at http://www.nber.org/ papers/w18398

256. Merkley \& Levin, supra note 248 , at 516.

257. For summaries of these three major cataclysmic events, see Brent Barker, Game Changer, PUB. POWER (June 11, 2013), available at http://publicpower.org/Media/magazine/ArticleDetail.cfm?Item Number =38099; Great Northeast Blackout, BLACKOUT HIST. PROJECT (June 27, 2000), http://blackout.gmu.edu/events/t11965.html; New York Blackout, BLACKOUT HIST. PROJECT (June 27,2000), http://blackout.gmu.edu/events/t11977.html.

258. See 16 U.S.C. $\$ \S 8240(a)(2)$, (c)(1) (2012). Under this section, FERC approves reliability standards that the Electric Reliability Organization (ERO) develops and submits to it.

259. Barkow, supra note 246 , at 18.

260. 12 U.S.C. $\$ 5511(2012)$.

261. Elizabeth Warren, Unsafe at Any Rate: If It's Good Enough for Microwaves, It's Good Enough for Mortgages, DEMOCRACY, Summer 2007, at 8.

262. Barkow, supra note 246 , at 72 . 
tion of inaction by the Federal Reserve and others in the face of warnings that risky mortgage products had become "a threat both to homeowners and to the financial system ...."263 Of course, the link between mortgage issues and the overall distress of the financial system in 2008 and thereafter has been widely documented. ${ }^{264}$

To address this problem, there were "extensive efforts to understand how it was possible that consumer lending by the nation's largest banks, directly, and through a variety of business fronts, went essentially unregulated during the period from 2003-2008, particularly in the area of home mortgages, the world's largest single financial market." ${ }^{265}$ This regulatory failure and the idea of establishing a new system of consumer protection reform in financial services were debated widely in numerous high-profile fora. ${ }^{266}$ In response, Dodd-Frank established the CFPB to ensure that "consumers are provided with timely and understandable information to make responsible decisions about financial transactions" and to protect consumers "from unfair, deceptive, or abusive acts and practices."267

One primary impetus for the CFPB's creation was a perception that protecting consumers was not a primary objective of financial regulation and took a back seat in regulators' perspectives to ensuring the soundness of the financial system. ${ }^{268}$ Another problem was that fragmented regulatory author-

263. Legislative Proposals to Reform the Consumer Financial Protection Bureau: Hearing Before the H. Subcomm. on Fin. Insts. E Consumer Credit, 113th Cong. 2 (2013) (statement of Damon A. Silvers, Policy Director and Special Counsel, American Federation of Labor and Congress of Industrial Organizations).

264. See, e.g., Dan Caplinger, Understanding the CFPB's New Mortgage Rules: Keeping You Safe From Tricky Loans, DAIIY FINANCE (Jan. 24, 2014, 12:50 PM), http://www.dailyfinance.com/2014/01/24/ understanding-the-cfpbs-new-mortgage-rules-keeping-you-safe-fr ("The worst financial crisis in generations resulted from a relatively simple problem: Millions of homeowners overextended themselves by borrowing more than they could afford, with the aid and encouragement of the banks. That helped artificially inflate home prices, and eventually led to a price collapse and a wave of mortgage defaults that brought the banking system to the brink of collapse.").

265. Legislative Proposals to Reform the Consumer Financial Protection Bureau: Hearing Before the H. Subcomm. on Fin. Insts. ES Consumer Credit, 113th Cong. 1 (2013) (statement of Damon A. Silvers, Policy Director and Special Counsel, American Federation of Labor and Congress of Industrial Organizations).

266. Id. at 1-2 (noting that this was the subject of "hearings in both houses of Congress, by the Congressional Oversight Panel for TARP as part of its mandate from Congress to make recommendations for regulatory reform, by the Congressionally mandated Financial Crisis Inquiry Commission, and in numerous academic and think tank studies").

267. Barkow, supra note 246, at 72 (quoting Dodd-Frank Wall Street Reform and Consumer Protection Act, Pub. L. No. 111-203, 124 Stat. 1376 (2010)).

268. Id. at 72-73; Barnett, supra note 246, at 29; see also Legislative Proposals to Reform the Consumer Financial Protection Bureau: Hearing Before the H. Subcomm. on Fin. Insts. E' Consumer Credit, 
ity aimed at protecting consumers from abuses in financial services allowed gaps that enabled abuses to proliferate. ${ }^{269}$ As one economist testified before a hearing on the House proposal to establish a consumer protection agency:

It is also clear that the current fractured regulatory framework overseeing consumer financial protection is wholly inadequate. Much of the most egregious mortgage lending during the housing bubble earlier in the decade was done by financial firms whose corporate structures were designed specifically to fall between the regulatory cracks. There is no way to end the regulatory arbitrage in the regulatory framework. The framework itself must be fundamentally changed. ${ }^{270}$

Before Dodd-Frank, numerous federal agencies regulated consumer credit and lending, including the Federal Reserve, Office of Comptroller of the Currency, Office of Thrift Supervision, Federal Deposit Insurance Corporation, and Federal Trade Commission (FTC). ${ }^{271}$ As an example of this, before Dodd-Frank, the Federal Reserve had rulemaking authority to implement the consumer protection laws, including the Truth in Lending Act, and the FTC had enforcement authority. ${ }^{272}$

The legislative solution aimed to consolidate regulatory authority in a single agency to deal with consumer financial protection, ${ }^{273}$ as Professor Warren had advocated. Proposals in the major financial regulatory reform bills advanced in both the House and Senate sought establishment of such an agency. ${ }^{274}$

113th Cong. 3 (2013) (statement of Damon A. Silvers, Policy Director and Special Counsel, American Federation of Labor and Congress of Industrial Organizations) (noting that with reform, "consumer protection would no longer be the stepchild of financial regulation").

269. Barnett, supra note 246, at 29-30; Experts' Perspectives on Systemic Risk and Resolution Issues: Hearing Before the H. Comm. on Fin. Servs., 111th Cong. 40 (2009) (statement of Mark Zandi, Chief Economist and Co-founder, Moody's Economy.com).

270. Id.

271. Leonard J. Kennedy, Patricia A. McCoy \& Ethan Bernstein, The Consumer Financial Protection Bureau: Financial Regulation for the Twenty-First Century, 97 CORNELL L. REV. 1141, 1145-46 (2012) (discussing the redistribution of agency power in the creation of the CFPB); The Dodd-Frank Act: How States and the Consumer Financial Protection Bureau Will Work Together to Protect Consumers, CONSUMER FED'N OF AM., http://www.consumerfed.org/pdfs/Fact $\% 20$ Sheet $\% 20 \mathrm{CFPB} \% 20$ and $\% 20$ the $\% 20$ States $\% 20 \mathrm{Nov} \% 202010 \% 20 \_3$.pdf.

272. Barnett, supra note 246, at 29; WEBEL ET AL., supra note 251, at 10.

273. Id. at Summary ("Another option would be to remove regulatory authority on a particular topic from the multiple agencies that might address it within their area now, and establish a single agency to address that issue. For instance, a single consumer financial protection agency ... could be created.").

274. Compare H.R. 4173, 111th Cong. $\$ 4101$ (2009) (establishing a "Consumer Financial Protection Agency" as an independent agency), with S. 3217, 111th Cong. $\$ 1011$ (a) (2010) (establishing the CFPB within the Federal Reserve). 
These proposals differed in various respects, one of which was the agency's location within the existing regulatory landscape. The House bill would have created a freestanding regulatory agency, while the Senate bill, which eventually became the basis for the CFPB's institutional framework, established the CFPB as a new agency in the Federal Reserve System. ${ }^{275}$ The debate over which of these obviously diverging policy paths to take was "hotly contested," and the prospect of agency capture by the financial industry (particularly if the consumer protection function was lodged within the existing structure) was an "obvious concern." ${ }^{276}$ But strenuous opposition from financial services companies and their powerful trade associations against a freestanding new agency on the basis that regulation of consumer protection and security of the financial system could not be handled separately derailed the House proposal. ${ }^{277}$

Another important issue that arose in the creation of the CFPB was the scope of the new agency's authority to promulgate new federal rules. ${ }^{278}$ The prospect that the new agency would make new rules, rather than simply enforcing existing ones more vigorously, led some industry interests to claim that it would hamper the competitiveness of financial services firms. ${ }^{279}$ One formulation of this dilemma was that the new agency "must strike the appropriate balance between underregulating, which will result in bad lending that pushes too many households toward bankruptcy or foreclosure, and overregulating, which will stifle innovation, restrict credit for creditworthy borrowers, and lead to higher costs for all consumers." 280

275. 12 U.S.C. $\$ 5491$ (2012); WEBEL ET AL., supra note 251, at 11 (describing the differences between the House and Senate proposals and noting that in the Senate bill, "rather than creating a new, free-standing regulatory agency like in H.R. 4173, the Bureau would be established within the Federal Reserve System."). See generally Hammond Meazell, supra note 247, at 1792 (discussing the risks inherent in this structure of interagency relationships).

276. Barnett, supra note 246, at 37; Barkow, supra note 246, at 72; Arthur E. Wilmarth, Jr., The Dodd-Frank Act's Expansion of State Authority to Protect Consumers of Financial Services, $36 \mathrm{~J}$ CORP. L. 893, 951 (2011) (observing that "Congress designed CFPB to be especially resistant to capture by the financial services industry, because members of Congress and analysts agreed that the industry had exercised excessive influence over bank regulators during the period leading up to the financial crisis").

277. Id. at 73 .

278. Id. at 74 (noting that the choice was whether the CFPB would have "independent rulemaking authority or if it would merely be an enforcement body that policed rules enacted by existing banking regulators").

279. Experts' Perspectives on Systemic Risk and Resolution Issues: Hearing Before the H. Comm. on Fin. Servs., 111th Cong. 40 (2009) (statement of Mark Zandi, Chief Economist and Co-founder, Moody'sEconomy.com).

280. Id. at 116 (written testimony of Mark Zandi, Chief Economist and Co-founder, Moody's Economy.com). 
In the end, Dodd-Frank specified that the CFPB has independent rulemaking authority. ${ }^{281}$ One principal focus of the agency's new rules has been on mortgage lenders' standards of conduct. An example is the 2013 Ability to Repay Rule, which implements Sections 1411 and 1412 of DoddFrank, that require creditors to make a "reasonable, good faith determination of a consumer's ability to repay any consumer credit transaction secured by a dwelling (excluding an open-end credit plan, timeshare plan, reverse mortgage, or temporary loan)," and "establishes certain protections from liability under this requirement for 'qualified mortgages." 282 The CFPB's rules are not subject to approval by the Federal Reserve or any other agency. Under the new law, the CFPB is "the only agency authorized to apply, enforce, interpret or administer the provisions of . . Federal consumer financial law." 283 There are, however, two checks on its rulemaking. First, the CFPB must consult with the Federal Reserve and other regulators that guarantee the financial system's safety before making rules. The Financial Stability Oversight Council, another new entity created in Dodd-Frank, provides a further check on the CFPB's work, as it may invalidate CFPB rules that threaten the financial system's safety. ${ }^{284}$

The proposal to give the CFPB new regulatory authority also sparked federalism concerns. Before Dodd-Frank, multiple federal agencies shared oversight of consumer credit and lending with state attorneys general and banking and credit regulators. ${ }^{285}$ Consumer advocates fought to retain a role for the states in consumer protection, arguing that "states should also be able to play their traditional role as first responders if abuses emerge that are not yet addressed by or fall in a gap in federal consumer protection rules. ${ }^{286} \mathrm{Fi}^{-}$ nancial services firms, by contrast, sought preemption of state laws. ${ }^{287}$ Section 1041 of Dodd-Frank adopts a floor preemption approach. Federal law preempts state law only if it is inconsistent with a federal consumer protection

281. 12 U.S.C. $\$ 5512(b)(4)(2012)$.

282. Ability-to-Repay and Qualified Mortgage Standards Under the Truth in Lending Act (Regulation Z), 78 Fed. Reg. 35,430, 35,497, 35,501 (June 12, 2013) (to be codified at 12 C.F.R. pt. 1026).

283. 12 U.S.C. $\$ 5512(\mathrm{~b})(4)(\mathrm{B})(2012)$; see also Hammond Meazell, supra note 247, at 1792 (contrasting this provision with the CFPB's oversight by the Financial Stability Oversight Council).

284. 12 U.S.C. $\$ 5513($ a) (2012); see Hammond Meazell, supra note 247, at 1792.

285. See Elosta, supra note 247, at 1302.

286. LAUREN SAUNDERS, NAT'L CONSUMER LAW CTR., THE ROLE OF THE STATES UndER the Dodd-Frank Wall Street Reform and Consumer Protection Act of 2010, at 9 (2010).

287. Barkow, supra note 246 , at 75 . 
law, but an inconsistency does not include providing greater protection to a consumer. ${ }^{288}$ Over industry objections, the new law also gives state attorneys general the power to enforce Dodd-Frank's prohibition against unfair, deceptive, and abusive acts and practices, and to enforce $\mathrm{CFPB}$ regulations. ${ }^{289}$

\section{Lessons for a Smart Electricity Network}

\section{a. Regulatory Lessons}

One lesson from the debate over the creation of the CFPB is that sweeping change in the regulation of an industry requires attention to fundamental questions of institutional design, jurisdiction, and functions. ${ }^{290}$ In particular, this is likely to be true in a situation where existing authority is perceived to be fragmented, replete with gaps, and not responsive to a major concern such as protecting consumers. As the development of Dodd-Frank indicates, the approach taken is unlikely to be simply a matter of closing the gaps with new regulatory authority. The resistance of entrenched industry entities to dramatic regulatory overhaul proposals will often result in compromises that may yield a distribution of authority not previously foreseen by those who promoted regulatory reform. The CFPB's regulatory institutional framework is unusual in modern times.

Similarly, sweeping changes in electric grid regulation might require some creativity in institutional design. Perhaps, for example, rather than simply postulating the potential for an OADT, we may need to reexamine whether FERC is the appropriate entity to be promulgating it, at least as currently constituted. It may appear at some point in time that FERC has subordinated the interests of advancing a smart electricity network to promoting other objectives (such as the grid's stability, comparable to the system of financial regulation before Dodd-Frank). At that point in time, Congress might move or reorganize the consumer-facing programs of FERC into a new entity and establish new authority that would in turn centralize responsibility for advancing consumer interests and promulgating the OADT.

A significant caveat is in order. The CFPB's establishment resulted in a new system of regulation of an entire industry and the creation of a web of

288. 12 U.S.C. $\$ 5551(\mathrm{a})(1)-(2)(2012)$.

289. Id. $\S 5552$.

290. See David A. Hyman \& William E. Kovacic, Why Who Does What Matters: Governmental Design, Agency Performance, the CFPB and PPACA (Jan. 6, 2014) (unpublished manuscript) (on file with authors) (noting with respect to the CFPB how the specific combination of regulatory functions and purposes can affect agency decision-making). 
new interagency relationships. ${ }^{291}$ This should make one cautious about extending the analogy too far between its creation and any conclusion that the OADT might not be possible under existing statutes and authority. Some of the most intriguing issues in designing and establishing the CFPB involved how completely new statutory authority should be designed to accomplish important and often contradictory objectives. That distinguishes it in part from electricity regulation, where the central questions of federal agency jurisdiction relate to construing the authority of a single agency (FERC) to interpret its mandates under existing statutes.

Still, many central concerns in both settings are the same, including a balance between protecting consumers and potentially hampering the ability of industry participants to create new products. One fundamental lesson from the CFPB's creation is that we must strike this balance through careful attention to regulatory design. If a new distribution of authority is necessary, it may take a new statute, akin to Title $X$ of Dodd-Frank, to reach the requisite result. Another lesson is that attention must be paid to the potential for erosion of authority once it is believed to have been firmly established. In 2013, for example, the House committee with jurisdiction over the CFPB held several hearings aimed at weakening the agency and featured agendas with such ominous sounding topics as "Legislative Proposals to Reform the Consumer Financial Protection Bureau." 292

The allocation of regulatory authority to preserve a federalism balance between the CFPB and state attorneys general also has important resonance for the creation of a smart electricity network. Like consumer protection law before Dodd-Frank, the states and federal government have a distinctly different, but at times overlapping, responsibility for protecting the interests of electric utility ratepayers. Creating a patchwork of individual state regulatory laws to advance the Smart Grid might hamper development of a national network. ${ }^{293}$ This in some respects is akin to the industry argument in DoddFrank that preemption of state consumer protection laws was warranted because

291. Hammond Meazell, supra note 247, at 1792.

292. Legislative Proposals to Reform the Consumer Financial Protection Bureau: Hearing Before the H. Subcomm. on Fin. Insts. $\sigma^{\circ}$ Consumer Credit, 113th Cong. 5 (2013) (statement of Damon A. Silvers, Policy Director and Special Counsel, American Federation of Labor and Congress of Industrial Organizations) ("Today, this Subcommittee takes up a series of measures-I believe nine bills - each of which is designed to weaken the CFPB, to deprive the CFPB of its status as a genuine bank regulator, and to effectively subordinate the CFPB to the too big to fail banks that dominate the markets the CFPB regulates.").

293. Eisen, supra note 4, at 35. 
the alternative would make it difficult for financial services firms to compete and to develop new products and services. ${ }^{294}$

Allowing states to retain substantial authority (enforcement authority and the floor preemption of retaining state laws tailored to the precise needs of individual states, ${ }^{295}$ as long as they are not inconsistent with national laws) was important for securing states' support for Dodd-Frank. In both the Dodd-Frank setting and the electric grid, commentators have described the resulting situation as "dynamic federalism." 296 Indeed, one recent commentator on the CFPB argues that Dodd-Frank promotes "an arrangement of governance whereby overlapping authority and competition between state and federal regulators in the area of consumer financial protection has the potential to make the preemption dilemma much less problematic." 297 This is an important lesson for the future of an OADT. As noted above, an OADT would preempt state laws such as net metering laws. Yet, it would also have to preserve the historic role of the states to address such matters as setting terms and conditions for financial soundness of industry participants and licensing of new entrants.

\section{b. Risks in Relying on the Model}

One obvious risk of drawing any fundamental lessons from the financial system regulatory reform model is that, as noted above, sweeping regulatory change in the financial system is often crisis-driven. This aspect of resonance between the two models makes the finance model somewhat less appealing as a foundation for legal change to establish a smart electricity network. No one seeks a crisis. If fundamental change in the electric grid is more appealing to the public because a crisis has taken place, ${ }^{298}$ we can imagine worst-case scenarios far more damaging than those that have take place so far: blackouts over wide geographic areas, terrorist attacks on centralized generation facilities, and so

294. See Barkow, supra note 246 , at 75 .

295. Id. at $75-76$.

296. Compare Elosta, supra note 247, at 1275 (discussing "dynamic federalism" in the institutional landscape of the CFPB), with Eisen, supra note 4, at 53 (discussing the dynamic approach of standard-setting for the Smart Grid that avoids disruptive jurisdictional clashes between federal agencies and state PUCs).

297. Elosta, supra note 247, at 1275.

298. See Cass R. Sunstein, On The Divergent American Reactions to Terrorism and Climate Change, 107 COLUM. L. REV. 503, 556 (2007) ("If the public's analysis of likely costs and benefits shifted, perhaps as a result of more vivid incidents of tangible harm, domestic controls on greenhouse gases, and American participation in international agreements, would be far more probable."). 
forth. The warning signs are clear: The current electric grid faces constant stress and is desperately in need of an overhaul, and like crumbling bridges on highways, is a candidate for systemic failure. Perhaps the most useful aspect of the finance model, then, is that we should not-and cannot-wait for this sort of disastrous event on the electric grid to prompt change.

Another unappealing aspect of the crisis-driven reforms in the financial sector model is that it is hardly apparent that a crisis would yield the desired public policy result. Indeed, just the opposite may be true. The problems that Dodd-Frank sought to address (for example, with the CFPB's creation) of "overlapping jurisdictions" and "gaps in oversight" in the regulatory infrastructure for financial services resulted from piecemeal development of a structure that evolved over decades, "largely in reaction to past financial crises, with new agencies and rules created to address the perceived causes of the particular financial problems at that time." 299 This suggests that even the reforms promised by Dodd-Frank will require time to evaluate and may require additional tinkering. In other areas of the law (for example, environmental law ${ }^{300}$ ), shaping law reactively rather than proactively can often make it difficult to select the appropriate policy prescription. For now, we do not know whether this will be case with the CFPB, but we must stay tuned for CFPB II.

\section{CONCLUSION}

Using an OADT to accelerate development of a smart electricity network would foster disruption of the current electric grid and could prompt a "dumb to smart" evolution similar to that of the telecommunications industry: the transformation of America's one-way electric grid with digital technologies and revolutionary consumer applications. At present, there are only small movements toward discussion of a network with the central characteristic of openness and facilitation of multidimensional seamless transactions. Early-stage policy changes are encouraging innovative products, but no technology has comprehensively displaced the existing one. As one article puts it, "New market entrants are beginning to deliver familiar services in new ways and a host of

299. WEBELET AL., supra note 251, at Summary.

300. See, e.g., Lincoln L. Davies, Alternative Energy and the Energy-Environment Disconnect, 46 IDAHO L. REV. 473, 493 (2010) ("Energy and environmental law are both reactive. They focus more on the end result than the starting cause."); Robert V. Percival, Who's Afraid of the Precautionary Principle?, 23 PACE ENVTL. L. REV. 21, 22 (2006) ("While precaution has long been an important aspiration of much of United States environmental law, in practice, regulatory policy generally has been reactive, rather than truly precautionary."). 
new technologies and capital solutions are waiting in the wings to supply growing demand for next generation products and services." 301

On numerous fronts, potentially disruptive technologies for the electricity system are being developed, deployed, and tested. It looks more likely than ever that a critical mass of technologies may emerge to eventually prompt the need for a network. Some policies (more transmission connected to renewables via Order 1000 , for example) ${ }^{302}$ look like the prototypes for open networks, but true network development is not taking place. Infrastructure and standards are evolving, yet there is no overriding consideration of a principle of open access. ${ }^{303}$ Implementing an OADT to provide this openness would require fundamental transformation of this heavily regulated industry. For one thing, it is by no means clear that utilities will accept competition through opening their distribution wires. Looking forward to the future, there is an increasingly pervasive fear on the part of utilities that, sooner rather than later, consumers with applications like rooftop solar and storage systems will bypass utilities for their electricity needs. In time, that might prompt utilities to discuss openness, similar to what took place in the telecommunications sector.

What is past is most assuredly prologue. Learning from three different models of transformative regulatory change in major industries suggests important lessons about near-term regulatory needs for open access and about market conditions that may make open access appropriate. In the electric grid, if FERC issued an OADT too soon or without state PUC cooperation, it risks serious backlash from entities that have a role in creating a smart electricity network. Yet if it waits too long, the preconditions may never be established. Rather than wait for a transformation and then grapple with the difficulties of establishing an open access principle, this Article recognizes that decades of preparatory work are necessary to set a foundation for open access, and then issue an OADT to establish full open access.

301. HENDRICKS \& JAMES, supra note 26 , at 15 .

302. Klass \&Wilson, supra note 215 , at 1825.

303. HENDRICKS \&JAMES, supra note 26, at 16. 